\title{
High-fat diet-induced obesity in animal models
}

\author{
Niloofar Hariri and Louise Thibault* \\ School of Dietetics and Human Nutrition, McGill University, Quebec, Canada
}

\begin{abstract}
Epidemiological studies have shown a positive relationship between dietary fat intake and obesity. Since rats and mice show a similar relationship, they are considered an appropriate model for studying dietary obesity. The present paper describes the history of using high-fat diets to induce obesity in animals, aims to clarify the consequences of changing the amount and type of dietary fats on weight gain, body composition and adipose tissue cellularity, and explores the contribution of genetics and sex, as well as the biochemical basis and the roles of hormones such as leptin, insulin and ghrelin in animal models of dietary obesity. The major factors that contribute to dietary obesity - hyperphagia, energy density and post-ingestive effects of the dietary fat - are discussed. Other factors that affect dietary obesity including feeding rhythmicity, social factors and stress are highlighted. Finally, we comment on the reversibility of high-fat diet-induced obesity.
\end{abstract}

Dietary obesity: Rats: Mice: High-fat diet

\section{Introduction}

Obesity is considered to be a major risk factor for chronic diseases such as CHD and hypertension, type 2 diabetes, and some types of cancer ${ }^{(1)}$. Its prevalence is increasing, with 400 million obese and 1.6 billion overweight adults around the world ${ }^{(1)}$. Although genetics plays a role in the regulation of body weight, body size and body composition and the metabolic response to feeding in humans ${ }^{(2-6)}$ and in animals $^{(7,8)}$, the increase in worldwide obesity in a short period of time cannot be explained by genetics; there are individual differences in genetic susceptibility to environmental factors such as diet ${ }^{(2,6,9-11)}$.

Dietary fat intake often has been claimed as responsible for the increase in adiposity. Human studies have shown that high-fat diets ( $\geq 30 \%$ of energy from fat) can easily induce obesity $^{(10,12-15)}$. Epidemiological studies conducted in countries such as China, Canada and the USA have shown that, when the average amount of fat in the diet increases, the incidence of obesity also increases ${ }^{(16-19)}$. This has led to a worldwide effort to decrease the amount of fat in the human diet.

Diets rich in fat not only induce obesity in humans but also make animals obese ${ }^{(20-22)}$. In both rats ${ }^{(23,24)}$ and mice ${ }^{(25,26)}$ a positive relationship has been found between the level of fat in the diet and body weight or fat gain. In the scientific literature it was first shown that rats consuming diets containing high proportions of fat gained weight faster than those on diets containing minimal amounts of fat ${ }^{(27,28)}$.
In 1949, obesity was induced for the first time in rats by ad libitum feeding of a semi-liquid palatable diet ${ }^{(29)}$. Then in 1953, Fenton \& Dowling used high-fat diets with fat at $50 \%$ of total energy in weanling mice to induce obesity; they called it nutritional obesity ${ }^{(30)}$ but the model was later renamed as dietary obesity ${ }^{(31)}$.

Since under-reporting is an important bias in epidemiological studies on diet and obesity in human subjects ${ }^{(32-34)}$, animal models have been widely utilised for experiments on dietary obesity ${ }^{(7,8,35,36)}$. Usually high-fat diets within the range of $30-78 \%$ of total energy intake are used ${ }^{(21)}$ either by adding a particular fat to the animal's diet or using an assortment of fat- and sugar-rich supermarket foods (cafeteria diet) - for studying obesity in rats ${ }^{(24,37-46)}$ and mice ${ }^{(25,47-52)}$. The use of high-carbohydrate-lowfat diets has not been found as efficient as high-fatlow-carbohydrate diets in inducing obesity ${ }^{(24,41,53)}$.

It has been reported that despite the growing problem of obesity, Canadians and Americans are eating less fat than a generation ago ${ }^{(54,55)}$. This shows that the increasing rate of obesity cannot be totally explained by high intakes of fat in the diet, suggesting that the type of fat may also play a role, although the results of the studies in human subjects and animals have not been conclusive ${ }^{(56)}$. Some studies have reported that not all fats are obesogenic and the dietary fatty acid profile rather than the amount of energy from fat is an important variable in developing dietary obesity ${ }^{(25,47,57-60)}$, but there is some controversy on this matter since there are

Abbreviation: ICV, intracerebroventricular.

* Corresponding author: Dr Louise Thibault, fax +1 514398 7739, email louise.thibault@mcgill.ca 
reports showing non-significant differences in final body weight and/or body-weight gain of the animals consuming various fatty acids ${ }^{(53,61-66)}$.

Other factors that may contribute to obesity induced by a diet rich in fat include failure to adjust oxidation of fat to the extra fat in the diet ${ }^{(15)}$, increase in adipose tissue lipoprotein lipase activity ${ }^{(67)}$, increased meal size and decreased meal frequency $^{(68)}$, as well as overconsumption of energy attributed to high energy density of the diet ${ }^{(69-72)}$, orosensory characteristics of fats and poorly satiating properties of the high-fat diets ${ }^{(22,69,70)}$. Reviews of dietary obesity describe potential mechanisms of body weight and food intake regulation involving the central nervous system - mainly the hypothalamus - neuropeptides such as ghrelin and neuropeptide $\mathrm{Y}$, and hormones such as insulin and leptin ${ }^{(73,74)}$. Adipose tissue per se is considered to be an endocrine organ that secretes cytokines such as IL-6 and TNF $\alpha$; thus obesity could possibly be regarded as a chronic inflammatory disease ${ }^{(73-76)}$.

Obesity occurs when energy uptake surpasses energy expenditure in the individual animal and so the stores of energy in body fat are enlarged, particularly in adipose tissues. Obesity involves both or either an increase in the number of adipocytes (hyperplasia) and their size (hypertrophy) $)^{(10,77,78)}$. Initially it was hypothesised that adipocyte number was determined in early childhood and that the obesity developed during adulthood was a result of an increase in adipocyte size ${ }^{(99,80)}$. However, it is now known that hyperplasia is an ongoing event not limited to childhood. At any stage of life when adipocytes enlarge to the point of hypertrophy, they release factors such as TNF $\alpha$ and insulin-like growth factor that stimulate hyperplasia of the adipocytes ${ }^{(76,77,81)}$. Conversely, recent studies on reversal of obesity in human subjects have found decreases not only in the size of the fat cells but also in their number: the loss of weight is followed by apopotosis of $\operatorname{adipocytes}^{(78,81)}$.

This paper summarises the present literature on factors that can play a role in the development of obesity and explores mechanisms that have been proposed for obesity induced by a diet rich in fat. The adequacy of the paradigm of high-fat diets in animal models of human obesity will be discussed. The possibility of reversing dietary obesity in animal models will be explored. Physical activity is another important factor in obesity; however, the present paper focuses on dietary factors only. Some reviews have been published about diverse areas of dietary obesity that have been cited in this introduction but the aim of the present review is to summarise the range of relevant results and to provide a conclusive coverage of the different aspects of obesity from high-fat diets in non-human species.

\section{Assessment of dietary obesity}

In animal models, as in humans, obesity can be assessed by criteria based on (1) gain of body weight or the Lee obesity index and/or (2) increase of body fat content. However, standard thresholds for obesity have not been developed like BMI in human beings. In most studies, the degree of obesity has been evaluated by comparing body weight (or fat) of the experimental group fed a high-fat or energy-dense diet with control animals that show normal growth while fed chow or low-fat diets $(20,24,41,42,45,82)$. Researchers that have attempted to do so differed in the values that are 10-25\% greater body weight than age-matched control rats fed chow (normal pattern of body-weight gain) as moderate obesity $^{(41,42)}$ and greater than $40 \%$ as severe obesity ${ }^{(82)}$.

The Lee index for assessing obesity in rats is similar to BMI in humans. It was defined by Lee in $1929^{(83)}$ as the cube root of body weight $(\mathrm{g})$ divided by the naso-anal length $(\mathrm{cm})$ and multiplied by 1000 . Lee considered values greater than 310 as an indicator of obesity. Since then some researchers have used the Lee index to assess the levels of obesity in rats ${ }^{(44,84-88)}$. Reliable correlations were found in some studies between the Lee index and fat content of the body ${ }^{(86,89-91)}$.

In human subjects body composition assessment with methods such as air displacement plethysmography or dualenergy X-ray absorptiometry gives a more precise idea of the degree of obesity than do anthropometric measurements alone $^{(92,93)}$. For example, children and adolescent males have smaller fat mass than females of a similar BMI, and this difference is more pronounced in the older age group; and so the relationship between BMI and the direct measures of adiposity is influenced by factors such as sex and age ${ }^{(92)}$. Dual-energy X-ray absorptiometry is also used in rats for assessing body composition ${ }^{(24,94)}$. In rats fed diets high in fat, a linear increase in body fat with increasing body weight has been shown ${ }^{(25,45)}$. However, results of the study of Woods et al. ${ }^{(42)}$ showed that measuring body fat is a more sensitive criterion for assessing obesity in animals, since rats fed a high-fat diet (40\% of energy) for 10 weeks displayed a $10 \%$ increase in total body weight but a $35-40 \%$ increase in total body fat compared with the animals fed a low-fat diet.

In models of dietary obesity, animals are classified as prone and resistant based on their body weight, body-weight gain, body fat, or noradrenaline concentrations in urine. Tulipano et al. ${ }^{(95)}$ categorised Sprague-Dawley rats fed a high-fat diet based on their final body weight, with rats in the highest quartile designated as obesity prone and those in the lowest quartile assigned as obesity resistant. In some studies upper (prone) and lower (resistant) tertiles of bodyweight gain ${ }^{(46,51,96)}$ or body fat ${ }^{(97)}$ of the animals fed highfat diets have been used for this classification. Before developing obesity while fed with chow, prone and resistant animals have also been identified based on high and low levels of urinary noradrenaline, respectively ${ }^{(98,99)}$.

\section{High-fat diets}

\section{Energy density}

In humans, a significant positive relationship has been found between the amount of dietary energy from fat and the proportion of the population who are overweight (in epidemiological studies), and in clinical studies between the level of dietary fat and body-weight gain as well as between the reduction in the dietary fat and weight loss $(16,17,19,100)$. These associations have also been shown in animal studies $^{(23-26,101)}$. This relationship in humans or in animal 
models of more dietary fat leading to greater obesity shows that the fat content of the diet is an important factor in energy balance. In general, diets containing more than $30 \%$ of total energy as fat lead to the development of obesity.

Researchers have induced obesity by diets having different percentages and sources of fats in $\operatorname{rats}^{(24,31,37-45,53,82,102-105)}$, mice mich- $^{(25,47-52,60)}$ and hamsters ${ }^{(106)}$. Furthermore, the characteristics of the diets used have differed within and between laboratories in macronutrient composition, energy density and orosensory properties. In many animal studies the composition of the control diet was not shown or a non-purified chow control diet was used. This could have confounding effects arising from comparisons made with the high-fat diets.

Since the original observations of dietary obesity, obesity has been induced in animals by diets containing fat as low as $13 \%$ of total energy in a high-energy $\operatorname{diet}^{(41)}$ (Table 1; line 26) (which is more than the rat's requirement for fat: $5 \%$ ) to as high as $85 \%$ of energy ${ }^{(37)}$ (Table 1; line 1). Several researchers have reviewed the amount of fat required to induce obesity in animals. The most recent review was by Buettner et al. ${ }^{(21)}$ who summarised studies conducted between 1997 and 2007, and concluded that the best method to induce obesity in animals was to use semi-purified highfat diets containing animal fats at $40 \%$ of energy, with a low amount of $n-3$ fatty acids and a low amount of plant oils rich in $n-6$ and $n-9$ fatty acids.

Interestingly, some recent studies have indicated that the development of obesity is prevented in humans and rats when the increase in dietary fat is accompanied by an increase in protein (high protein:carbohydrate and low carbohydrate:fat ratios) ${ }^{(107-109)}$. This has been related to greater satiety with high-protein diets, lower insulin levels with low-carbohydrate diets and the energy required to convert amino acids in glucose compounds for gluconeogenesis $^{(107)}$. High-protein diets were also found to increase cholecystokinin and decrease plasma levels of the orexigenic hormone ghrelin $^{(110,111)}$, reduce gastric emptying $^{(11)}$ and increase central nervous system leptin sensitivity ${ }^{(109,112)}$. Moreover, high-protein diets resulted in a decrease in fatty acid synthase enzyme activity in the liver that reduces hepatic lipogenesis ${ }^{(107)}$. The increase in circulating amino acids per se is a satiety signal and inhibits food intake through suppressing the gene expression of agouti-related protein (a neuropeptide in the brain that increases appetite $)^{(110,113)}$. However, Huang et al. ${ }^{(114)}$ showed that increasing the dietary protein:carbohydrate ratio could not reduce the degree of obesity when obesity had already been induced in high-fat diet-fed mice (at $40 \%$ of energy). Therefore they suggested that these diets might be efficient in preventing obesity but may not reverse obesity once established.

In the human diet, an increase in dietary fat is usually accompanied by a decrease in carbohydrate while the protein is relatively constant (for example, fat $35-45 \%$, carbohydrate $45-55 \%$, protein $15-20 \%$ ). This is why a presumably positive relationship between the level of fat of the diet and degree of obesity is usually found in epidemiological studies without controlling for dietary protein level.

\section{Dietary profile of fatty acids}

Fatty acid composition of the diet may play an important role in body-weight regulation and cellularity of adipose tissue (fat cell volume and number) ${ }^{(56,59,115,116)}$. Studies in human subjects have shown that SFA are more obesogenic than PUFA ${ }^{(57,58,117-119)}$. This idea has been supported by animal studies by showing either greater accumulation of body fat ${ }^{(43,47,120-122)}$ (Table 1; lines 19, 21, 16, 18 and 37 , respectively) or higher body weight ${ }^{(25,47,60,122)}$ (Table 1; lines 11, 21, 33 and 18, respectively) on feeding with diets moderate or rich in SFA. A study conducted by Ellis et al. ${ }^{(53)}$ in 3-week-old female Sprague-Dawley rats comparing diets rich in low-SFA maize oil or high-SFA coconut oil (40\% of total energy) for 8 weeks found higher fat cell number in animals fed coconut oil and greater fat cell size in the rats fed maize oil. Since hypertrophy of adipocytes is a prerequisite for hyperplasia, those results show that more severe form of obesity developed from feeding a diet high in SFA.

The obesogenic effect of SFA can be explained by the fact that SFA are poorly used for energy, and so remain to be acylated into TAG and stored in adipose tissue, whereas PUFA and MUFA are readily used for energy and so stored less ${ }^{(59)}$. In other words, the effective energy content of a diet is greater when the fats in it are high in SFA. In addition, the rate of oxidation of SFA decreases with increase of carbon chain length $^{(57)}$. Furthermore, unlike MUFA and PUFA, SFA decrease RMR and diet-induced thermogenesis ${ }^{(116,118,123-125)}$. Moussavi et al. ${ }^{(56)}$ suggested that PUFA suppress the expression of lipogenic transcription genes while MUFA and SFA do not.

Another possible mechanism is that saturation of fatty acids decreases their suppressive effect on dietary intake: thus fats and oils containing high proportions of linoleic acid are more satiating than fats and oils rich in oleic or

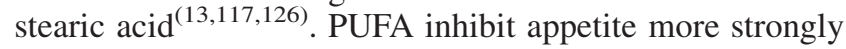
than MUFA or SFA through an increase in the release of cholecystokinin which augments other signals of satiety ${ }^{(117,126)}$. Another study, however, failed to confirm that SFA induced less satiety than MUFA ${ }^{(127)}$.

A study in adult male Wistar rats showed that feeding high-fat diets $(60 \%$ of energy) for 8 weeks resulted in greater intrathoracic fat mass in animals fed a SFA-rich diet (cocoa butter) and greater intra-abdominal and epididymal fat mass in those fed PUFA (safflower-seed oil) ${ }^{(61)}$ (Table 1; line 38). There are also reports of studies that did not show any specific effect of SFA and PUFA on body weight or fat mass $^{(64,128)}$ (Table 1; lines 17 and 25, respectively).

Short-chain (C2:0-C4:0) and medium-chain (C6:0$\mathrm{C} 12$ :0) fatty acids are directly transported to the liver via the portal system, are not dependent upon carnitine for entering the mitochondria and therefore are oxidised more and deposited less in adipose tissue than long-chain fatty acids (C14 : 0-C24:0) ${ }^{(56,129,130)}$. Short-chain and mediumchain fatty acids also increase diet-induced thermogenesis and energy expenditure ${ }^{(56,130)}$. The lower obesogenic effect of medium-chain TAG, which are composed of mediumchain fatty acids, was shown in many studies. Isoenergetic diets (with fat at $12 \%$ of total energy) containing olive oil or medium-chain fatty acid (octanoic acid) offered for $23 \mathrm{~d}$ to 


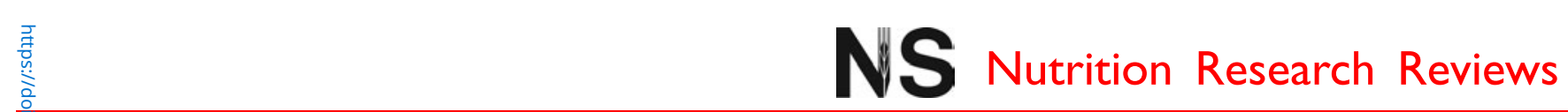

\begin{tabular}{|c|c|c|c|c|c|c|c|c|c|c|c|c|c|c|}
\hline \multirow[b]{3}{*}{ Reference } & \multirow[b]{3}{*}{$\begin{array}{l}\text { Species, strain, } \\
\text { sex, weight, age }\end{array}$} & \multicolumn{6}{|c|}{ Diet composition } & \multirow[b]{3}{*}{$\begin{array}{l}\text { Duration } \\
\text { (weeks) }\end{array}$} & \multicolumn{5}{|c|}{ Changes in body weight and dietary intake } & \multirow[b]{3}{*}{ Line no. } \\
\hline & & \multirow[b]{2}{*}{ DIO diet } & \multicolumn{2}{|c|}{$\begin{array}{c}\text { Amount } \\
\text { of fat }\end{array}$} & \multirow[b]{2}{*}{ Control diet } & \multicolumn{2}{|c|}{ Amount of fat } & & \multirow[b]{2}{*}{$\begin{array}{l}\text { Final/daily } \\
\text { body } \\
\text { weight (g) }\end{array}$} & \multirow[b]{2}{*}{$\begin{array}{c}\text { Body-weight } \\
\text { gain (g) }\end{array}$} & \multirow[b]{2}{*}{ Body fat $(\mathrm{g})$} & \multirow[b]{2}{*}{$\begin{array}{c}\begin{array}{c}\text { Food } \\
\text { intake }(g)\end{array} \\
\text { in }\end{array}$} & \multirow[b]{2}{*}{$\begin{array}{l}\text { Energy } \\
\text { intake }\end{array}$} & \\
\hline & & & $\begin{array}{c}g / 100 \mathrm{~g} \\
\text { diet }\end{array}$ & $\begin{array}{l}\% \text { of } \\
\text { total } \\
\text { energy }\end{array}$ & & $\mathrm{g} / 100 \mathrm{~g}$ diet & $\begin{array}{l}\% \text { of } \\
\text { total } \\
\text { energy }\end{array}$ & & & & & & & \\
\hline \multirow[t]{2}{*}{$\begin{array}{l}\text { Mickelsen etal. } \\
(1955)^{\left.()^{37}\right)}\end{array}$} & $\begin{array}{l}\text { Rats, Osborne- } \\
\text { Mendel, male, }\end{array}$ & $g / 100 \mathrm{~g}$ & & & $g / 100 \mathrm{~g}$ & & & & & & & & & \\
\hline & $300 \mathrm{~g}$, adult & $\begin{array}{l}60 \text { Crisco }{ }^{\oplus} \text { (Proctor \& } \\
\text { Gamble, Cincinnati, } \\
\text { OH, USA) } \\
25 \text { casein } \\
7 \text { sucrose } \\
1 \text { starch } \\
4 \text { mineral salts } \\
3 \text { cottonseed oil } \\
\text { containing: } \\
2 \text { vitamin A and D } \\
1 \text { vitamin E }\end{array}$ & 63 & 85 & $\begin{array}{l}30 \text { casein } \\
61 \text { sucrose } \\
2 \text { starch } \\
4 \text { mineral salts } \\
3 \text { cottonseed } \\
\text { oil containing: } \\
2 \text { vitamin A and D } \\
1 \text { vitamin E }\end{array}$ & 3 & 7 & 41 & i & $\mathrm{nr}$ & - & - & - & 1 \\
\hline \multirow[t]{2}{*}{$\begin{array}{l}\text { Schemmel } \\
\text { et al. } \\
(1969)^{(45)}\end{array}$} & $\begin{array}{l}\text { Rats, Osborne- } \\
\text { Mendel, male } \\
\text { and female, } \\
57.5 \pm 6.4 \mathrm{~g} \\
\text { (female), } \\
51.6 \pm 3.1 \mathrm{~g} \\
\text { (male), } 3.5 \\
\text { weeks }\end{array}$ & g/100 g & & & & & & & & & Total & & & \\
\hline & & $\begin{array}{l}60 \text { Crisco }^{\oplus} \\
25 \text { casein liver } \\
2 \text { liver powder } \\
0.25 \text { DL-methionine } \\
5 \text { mineral mix } \\
2.2 \text { vitamin mix } \\
0.01 \text { auremycin } \\
2 \text { fibre }\end{array}$ & 60 & 78 & Grain & $\mathrm{nr}$ & $\mathrm{nr}$ & 65 & $\mathrm{i}$ & $\mathrm{nr}$ & i & - & - & 2 \\
\hline \multirow[t]{2}{*}{$\begin{array}{l}\text { Herberg et al. } \\
\qquad(1974)^{(49)}\end{array}$} & $\begin{array}{l}\text { Mice, NMRI, male, } \\
19 \cdot 2 \pm 0.2 \mathrm{~g} \\
\text { (DIO diet), } \\
19.3 \pm 0.2 \mathrm{~g} \\
\text { (control diet), } \\
4 \text { weeks }\end{array}$ & g/100g & & & $g / 100 \mathrm{~g}$ & & & & & & $\begin{array}{l}\text { Epididymal and } \\
\text { subcu- } \\
\text { taneous }\end{array}$ & & kcal & \\
\hline & & $\begin{array}{l}38 \text { soya oil } \\
24 \text { casein } \\
10 \text { starch } \\
16 \text { sucrose } \\
5 \text { powdered celllulose } \\
1 \text { vitamin mix } \\
6 \text { mineral mix }\end{array}$ & 38 & 63 & $\begin{array}{l}20 \text { protein } \\
30 \text { oatmeal } \\
24 \text { whole meal } \\
13 \text { flour } \\
7 \text { wheat } \\
2.2 \text { sweet whey } \\
2.5 \text { distillers solubles } \\
0.2 \text { vitamin mix } \\
1.1 \text { mineral mix }\end{array}$ & 6.2 & 13 & $11-12$ & $\mathrm{i}$ & $\mathrm{i}$ & $\mathrm{i}$ & d & 0 & 3 \\
\hline \multirow[t]{2}{*}{$\begin{array}{l}\text { Lemonnier } \\
\text { et al. } \\
(1975)^{(50)}\end{array}$} & $\begin{array}{l}\text { Mice, Swiss, male } \\
\text { and female, }\end{array}$ & $\mathrm{g} / 100 \mathrm{~g}$ & & & $\%$ of total energy & & & & & & Genital & & & \\
\hline & & $\begin{array}{l}53 \text { lard } \\
\% \text { of energy } \\
72 \text { lipid } \\
22 \text { protein } \\
6 \text { carbohydrate }\end{array}$ & 53 & 72 & $\begin{array}{l}9 \text { lipid } \\
22 \text { protein } \\
69 \text { carbohydrate }\end{array}$ & 4.5 & 9 & & $\mathrm{i}$ & $\mathrm{nr}$ & $\mathrm{i}$ & - & - & 4 \\
\hline \multirow[t]{2}{*}{$\begin{array}{l}\text { Sclafani \& } \\
\text { Springer } \\
(1976)^{(228)}\end{array}$} & $\begin{array}{l}\text { Rats, CFE, female, } \\
234-239 \mathrm{~g}, \\
17 \text { weeks }\end{array}$ & $\mathrm{g} / 100 \mathrm{~g}$ & & & & & & & & & & & & \\
\hline & & $\begin{array}{l}33 \text { Crisco } \\
67 \text { Purina chow + } \\
\text { sweetened condensed } \\
\text { milk + palatable super- } \\
\text { market foods: chocolate } \\
\text { chip cookies, salami, } \\
\text { banana, marshmallows, } \\
\text { milk chocolate, peanut } \\
\text { butter }\end{array}$ & $>33$ & $>52.5$ & $\begin{array}{l}\text { Purina chow (company } \\
\text { not specified) }\end{array}$ & 4.5 & 9.6 & $8-9$ & $\mathrm{nr}$ & $\mathrm{i}$ & - & - & - & 5 \\
\hline
\end{tabular}




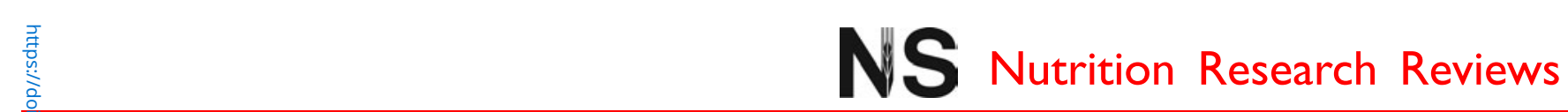

\begin{tabular}{|c|c|c|c|c|c|c|c|c|c|c|c|c|c|c|}
\hline \multirow[b]{3}{*}{ Reference } & \multirow[b]{3}{*}{$\begin{array}{l}\text { Species, strain, } \\
\text { sex, weight, age }\end{array}$} & \multicolumn{6}{|c|}{ Diet composition } & \multirow[b]{3}{*}{$\begin{array}{l}\text { Duration } \\
\text { (weeks) }\end{array}$} & \multicolumn{5}{|c|}{ Changes in body weight and dietary intake } & \multirow[b]{3}{*}{ Line no. } \\
\hline & & & \multicolumn{2}{|c|}{$\begin{array}{c}\text { Amount } \\
\text { of fat }\end{array}$} & \multicolumn{3}{|c|}{ Amount of fat } & & \multirow[b]{2}{*}{$\begin{array}{c}\text { Final/daily } \\
\text { body } \\
\text { weight (g) }\end{array}$} & \multirow[b]{2}{*}{$\begin{array}{l}\text { Body-weight } \\
\text { gain (g) }\end{array}$} & \multirow[b]{2}{*}{ Body fat $(g)$} & \multirow[b]{2}{*}{$\begin{array}{c}\text { Food } \\
\text { intake (g) }\end{array}$} & \multirow[b]{2}{*}{$\begin{array}{l}\text { Energy } \\
\text { intake }\end{array}$} & \\
\hline & & DIO diet & $\begin{array}{c}g / 100 \mathrm{~g} \\
\text { diet }\end{array}$ & $\begin{array}{l}\% \text { of } \\
\text { total } \\
\text { energy }\end{array}$ & Control diet & $\mathrm{g} / 100 \mathrm{~g}$ diet & $\begin{array}{l}\% \text { of } \\
\text { total } \\
\text { energy }\end{array}$ & & & & & & & \\
\hline $\begin{array}{l}\text { Sclafani \& } \\
\text { Gorman } \\
(1977)^{(44)}\end{array}$ & $\begin{array}{l}\text { Rats, CFE, male } \\
\text { and female, } \\
308 \mathrm{~g} \text { and } 12 \\
\text { weeks (male), } \\
233 \mathrm{~g} \text { and } 13 \\
\text { weeks (female) }\end{array}$ & $\begin{array}{l}\text { Purina chow + supermarket } \\
\text { foods: marshmallows, } \\
\text { cheese puffs, sugar- } \\
\text { coated cureal, chocolate } \\
\text { cookies, peanut butter, } \\
\text { bologna, sweetened } \\
\text { condensed milk }\end{array}$ & $\mathrm{nr}$ & $\mathrm{nr}$ & $\begin{array}{l}\text { Purina chow (company } \\
\text { not specified) }\end{array}$ & 4.5 & 9.6 & 8.5 & $\mathrm{nr}$ & $\mathrm{i}$ & - & - & - & 6 \\
\hline \multirow[t]{2}{*}{$\begin{array}{l}\text { Faust et al. } \\
\qquad(1978)^{(103)}\end{array}$} & $\begin{array}{l}\text { Rats, Sprague- } \\
\text { Dawley and } \\
\text { OSborne- } \\
\text { Mendel, male, }\end{array}$ & $\mathrm{g} / 100 \mathrm{~g}$ & & & & & & & & & $\begin{array}{l}\text { Retroperitoneal } \\
\text { and gona- } \\
\text { dal }\end{array}$ & & & \\
\hline & nr, ir weeks & $\begin{array}{l}55 \text { Criscoø } \\
25 \text { casein } \\
13 \text { dextrose } \\
4 \text { mineral salts } \\
2.82 \text { vitamin mix } \\
0.12 \text {-cystine } \\
0.06 \text { L-cysteine }\end{array}$ & 55 & 76 & $\begin{array}{l}\text { Purina chow (company } \\
\text { not specified) }\end{array}$ & 4.5 & 9.6 & 8.5 & $i$ (both strains) & $\mathrm{nr}$ & $i$ (both strains) & - & - & 7 \\
\hline \multirow[t]{2}{*}{$\begin{array}{l}\text { Oscai } \\
\quad(1982)^{(38)}\end{array}$} & $\begin{array}{l}\text { Rats, Wistar, } \\
\text { female, } \mathrm{nr},\end{array}$ & $\mathrm{g} / 100 \mathrm{~g}$ & & & & & & & & & Total & & & \\
\hline & weaning & $\begin{array}{l}4.84 \text { maize oil } \\
18.16 \text { lard } \\
18 \text { casein } \\
49.5 \text { sucrose } \\
2 \text { brewer's yeast } \\
2 \text { liver powder } \\
4 \text { Hegsted salt mixture } \\
1.5 \text { vitamin mix }\end{array}$ & 23 & 42 & $\begin{array}{l}\text { Purina chow (Ralston } \\
\text { Purina, Nestlé Purina } \\
\text { PetCare, St Louis, } \\
\text { MO, UAA) }\end{array}$ & 4.5 & 9.6 & 58 & $\mathrm{i}$ & $\mathrm{nr}$ & $\mathrm{i}$ & $\mathrm{nr}$ & - & 8 \\
\hline \multirow[t]{2}{*}{$\begin{array}{l}\text { Wade } \\
\qquad(1982)^{(106)}\end{array}$} & $\begin{array}{l}\text { Hamsters, golden, } \\
\text { male and } \\
\text { female, } \\
80-110 \mathrm{~g} \text {. nr }\end{array}$ & & & & & & & & & & Total & & kcal & \\
\hline & & $\begin{array}{l}\text { Two parts Purina chow } \\
\text { (Purina Rodent Chow, } \\
\text { no. } 501 \text { ) } \\
\text { One part vegetable short- } \\
\text { ening (company not } \\
\text { specified) }\end{array}$ & $>33$ & $>52.5$ & $\begin{array}{l}\text { Purina chow } \\
\text { (Purina Rodent Chow, } \\
\text { no. 5001) }\end{array}$ & 4.5 & 9.6 & 4 & $\mathrm{nr}$ & $\mathrm{i}$ & $\mathrm{i}$ & $\mathrm{nr}$ & 0 & 9 \\
\hline \multirow[t]{3}{*}{$\begin{array}{l}\text { Bourgeois etal. } \\
(1983)^{(25)}\end{array}$} & $\begin{array}{l}\text { Mice, NMRI, male } \\
\text { and female, nr, } \\
4 \text { weeks }\end{array}$ & $\mathrm{g} / 100 \mathrm{~g}$ & & & $g / 100 \mathrm{~g}$ & & & & & & $\begin{array}{l}\text { Retroperitoneal } \\
\text { and para- } \\
\text { metrial }\end{array}$ & & & \\
\hline & & $\begin{array}{l}5 \text { lard } \\
3.2 \text { bran } \\
0.3 \mathrm{DL}-\text { methionine } \\
4.3 \text { mineral mix } \\
2.4 \text { vitamin mix } \\
14 \text { casein } \\
70.8 \text { whe }\end{array}$ & 5 & 6.9 & $\begin{array}{l}78.5 \text { wheat flour } \\
12.1 \text { casein } \\
3 \text { bran } \\
0.4 \text { D-methionine } \\
2.1 \text { vitamin mix } \\
3.9 \text { mineral mix }\end{array}$ & 3 & 6.1 & 13 & 0 & $\mathrm{nr}$ & 0 & - & - & 10 \\
\hline & & $\begin{array}{l}70.8 \text { wheat flour } \\
10 \text { lard } \\
3.5 \text { bran } \\
0.2 \mathrm{~L}-\mathrm{m} \text { methionine } \\
4.6 \mathrm{~m} \text { meral mix } \\
2.5 \text { vitamin mix } \\
17 \text { casein } \\
62 \text { wheat flour } \\
20 \text { lard } \\
3.9 \text { bran } \\
0.1 \text { L-methionine } \\
5.2 \text { mineral mix } \\
2.9 \text { vitamin mix } \\
21.9 \text { casein } \\
45.5 \text { wheat flour }\end{array}$ & 20 & 26.8 & & & & & $i$ (female only) & $\mathrm{nr}$ & 0 & - & - & \\
\hline
\end{tabular}



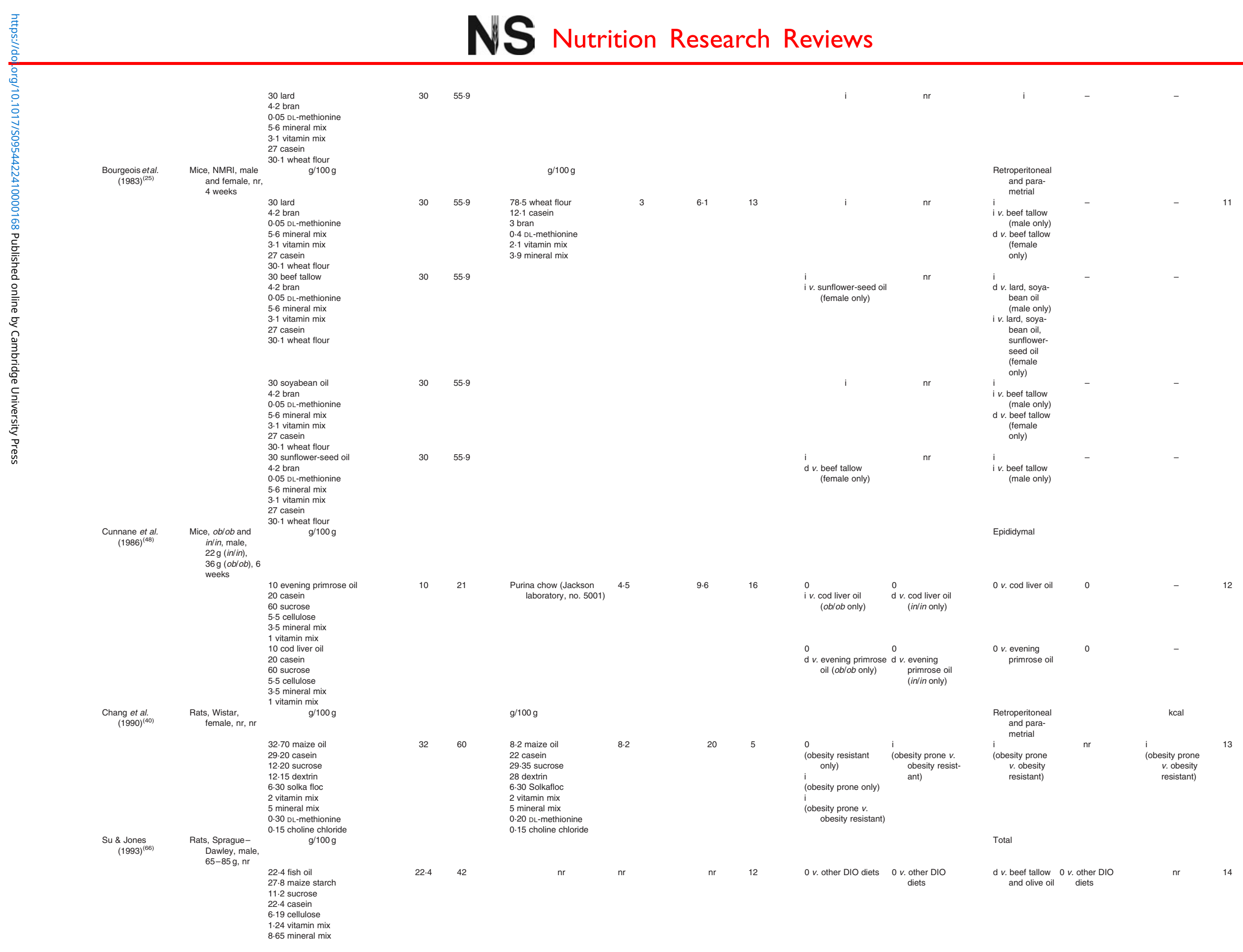


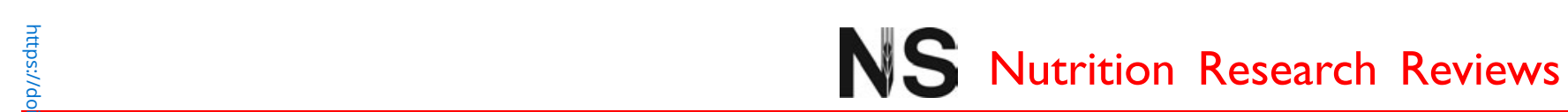

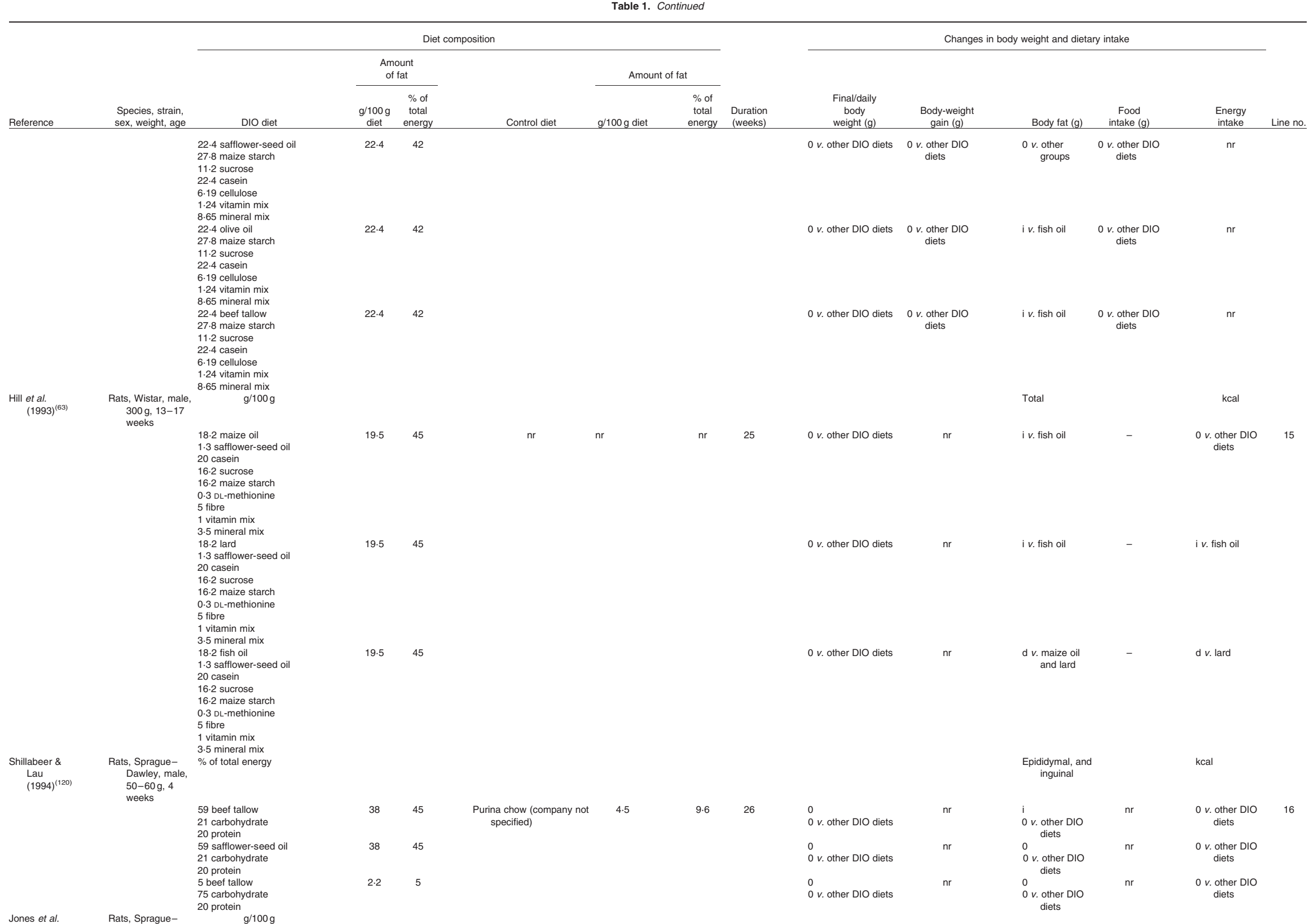

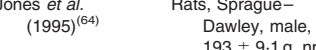
Dawley, male,
$193 \pm 9.1 \mathrm{~g}, \mathrm{nr}$ 

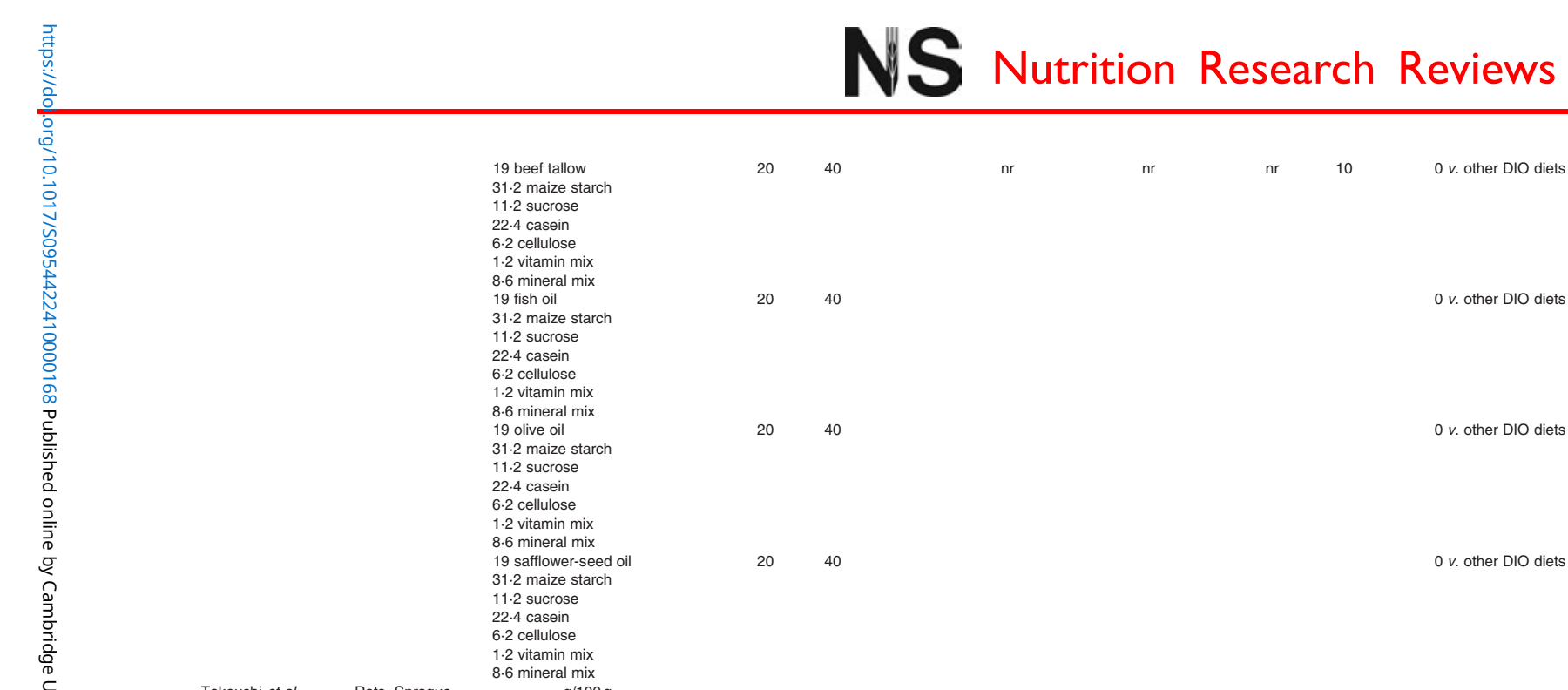

Takeuchi et al.
$(1995)^{(122)}$
Rats, Sprague-
Dawley, mal

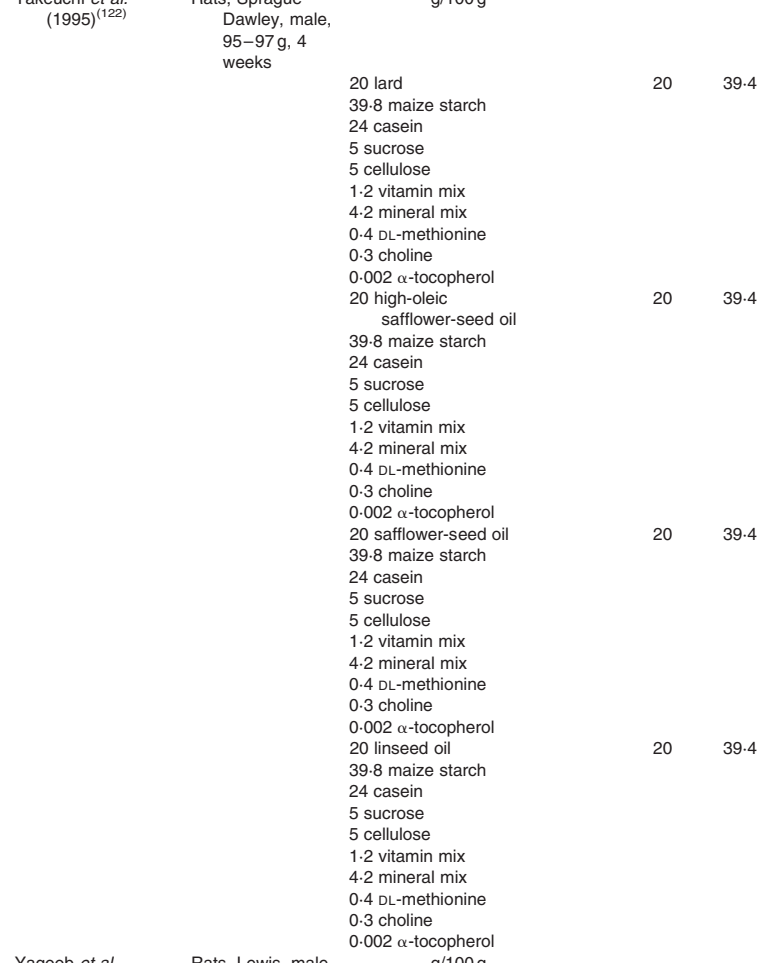

$0 v$. other DIO diets

$0 v$. other DIO diets

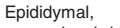

perinephrial

perinephrial
and mesen-
teric

iv. high-oleic saf-
flower-seed-

vagh-oleic
saftlower-
seed oil

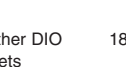

$\begin{aligned} & \text { seed oil, } \\ & \text { safflower- } \\ \text { seed oil and } & \text { sed }\end{aligned}$

v. other
diets

seed oil and
linseed oil

$d v$. lard

d v. lard

0 v. other DIO
diets

v. other DIO diets

v. other DIO
diets

$d v$. lard

$d v$. lard

v. other DIO

Epididymal 


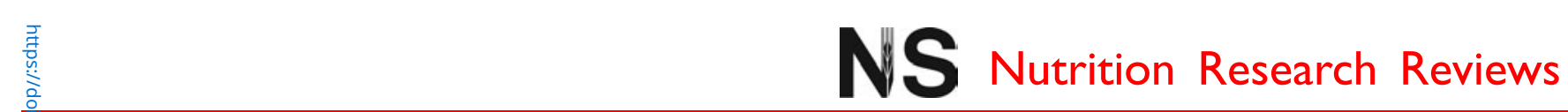

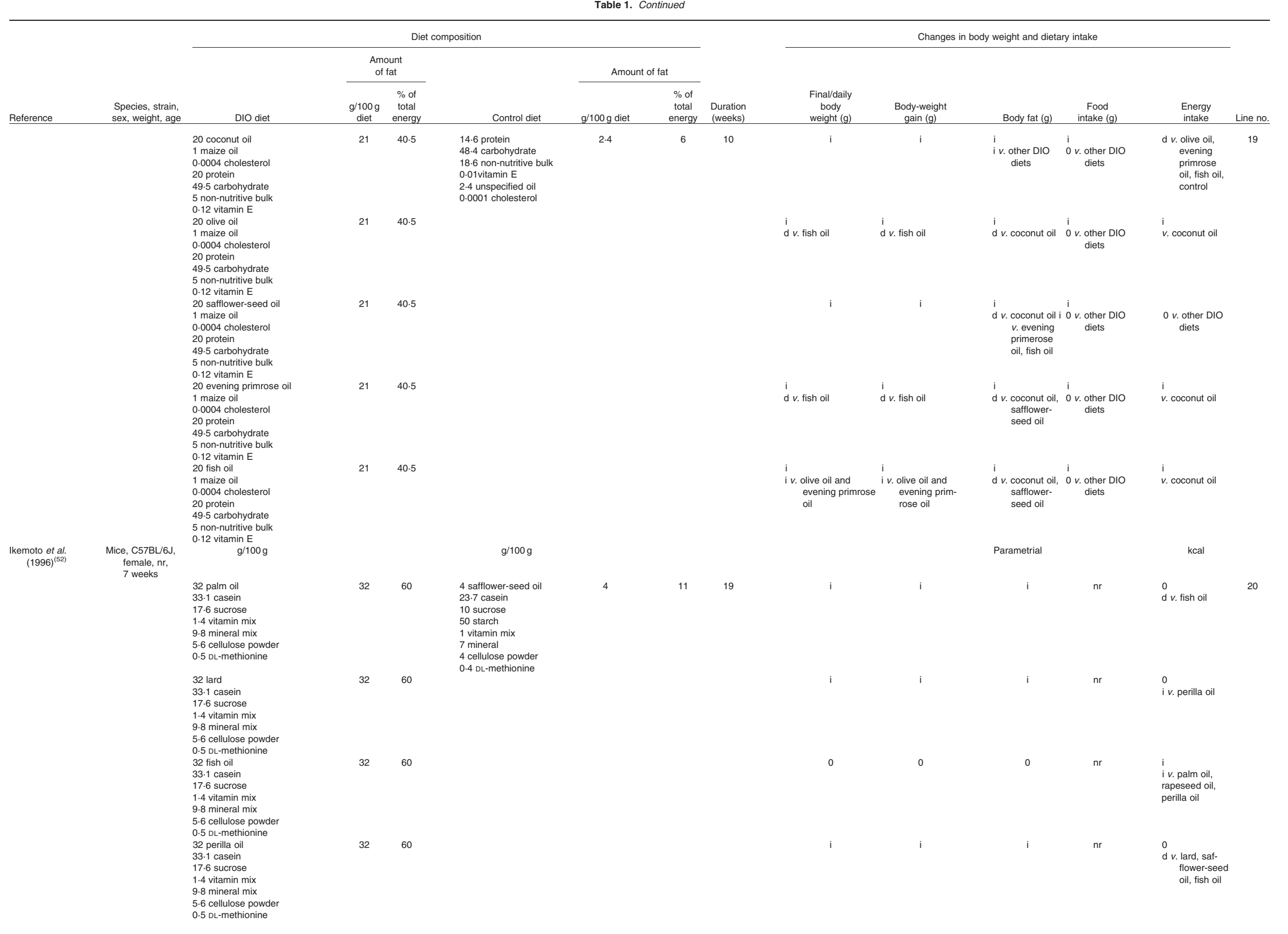



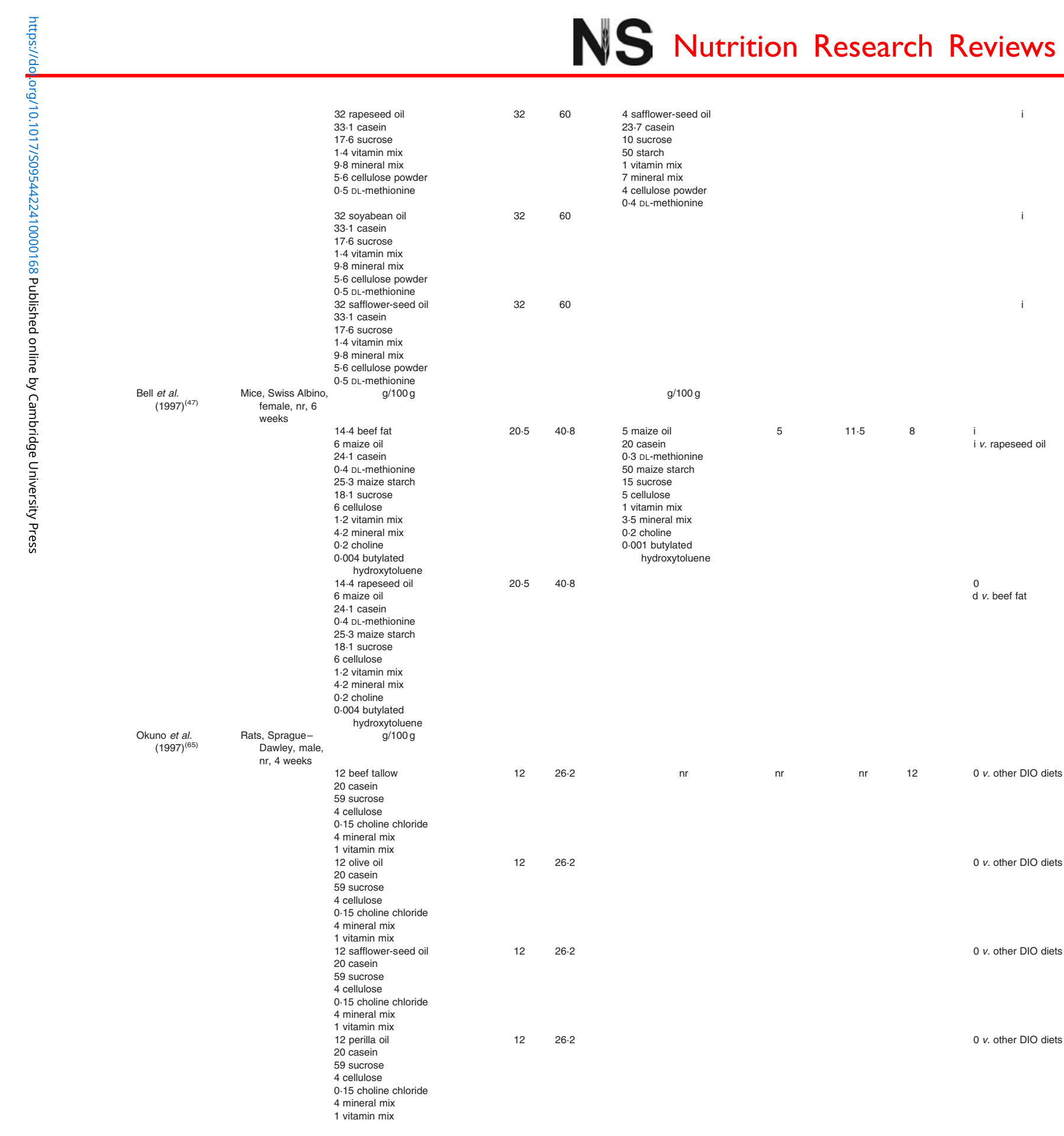

0
$d v$. fish oil

1 vitamin mix

4 cellulose powder
0.4 DL-methionine

6 cellulose powder

8 mineral mix

5 DL-methionine
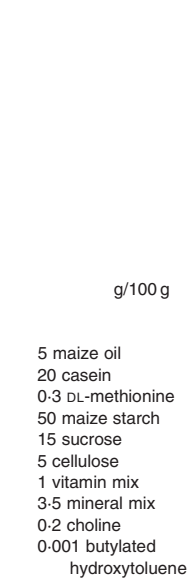

0.001 butylated
hydroxytoluene

25.3 maize starch

Okuno et al.
$(1997)^{(65)}$

$26 \cdot 2$

nr

$0 v$. other DIO diets

$0 v$. other DIO
diets

i v. perilla oil

$v$. beef fat

v. other DIO diets

$v$. perilla oil $0 v$. other DIO

$0 v$. other DIO diets

$v$. other DIO $0 v$. other DIO
diets

$d v$. beef tallow, $0 v$. other DIO 


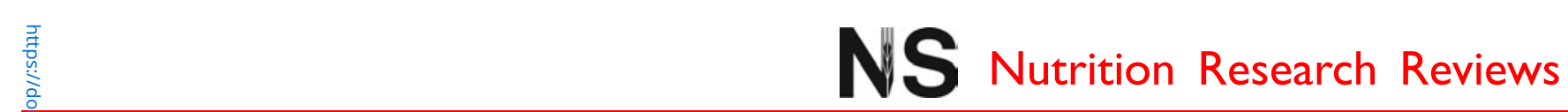

\begin{tabular}{|c|c|c|c|c|c|c|c|c|c|c|c|c|c|c|}
\hline \multirow[b]{3}{*}{ Reference } & \multirow[b]{3}{*}{$\begin{array}{l}\text { Species, strain, } \\
\text { sex, weight, age }\end{array}$} & \multicolumn{6}{|c|}{ Diet composition } & \multirow[b]{3}{*}{$\begin{array}{l}\text { Duration } \\
\text { (weeks) }\end{array}$} & \multicolumn{6}{|c|}{ Changes in body weight and ditatary intake } \\
\hline & & \multirow[b]{2}{*}{ DIO diet } & \multicolumn{2}{|c|}{$\begin{array}{c}\text { Amount } \\
\text { of fat }\end{array}$} & \multirow[b]{2}{*}{ Control diet } & \multicolumn{2}{|c|}{ Amount of tat } & & \multirow[b]{2}{*}{$\begin{array}{l}\text { Finaldaliy } \\
\text { bodyd } \\
\text { weight (g) }\end{array}$} & \multirow[b]{2}{*}{$\begin{array}{l}\text { Body-weight } \\
\text { gain (g) }\end{array}$} & \multirow[b]{2}{*}{ Body fat (g) } & \multirow[b]{2}{*}{$\begin{array}{l}\text { Food } \\
\text { intake (g) }\end{array}$} & \multirow[b]{2}{*}{$\begin{array}{l}\begin{array}{c}\text { Energy } \\
\text { intake }\end{array} \\
\text { int }\end{array}$} & \multirow[b]{2}{*}{ Line no. } \\
\hline & & & $\begin{array}{c}g / 100 g \\
\text { diet } \\
\end{array}$ & $\begin{array}{l}\% \text { of } \\
\text { total } \\
\text { energy }\end{array}$ & & $\mathrm{g} / 100 \mathrm{~g}$ diet & $\begin{array}{l}\% \text { of } \\
\text { total } \\
\text { energy }\end{array}$ & & & & & & & \\
\hline \multirow[t]{4}{*}{$\begin{array}{l}\text { Cha \& Jones } \\
\text { (1998)(62) }\end{array}$} & $\begin{array}{l}\text { Rats, Sprague- } \\
\text { Dawley, male, }\end{array}$ & g/100g & & & & & & & & & Perirenal & & & \\
\hline & $209 \pm 6.59, \mathrm{nr}$ & 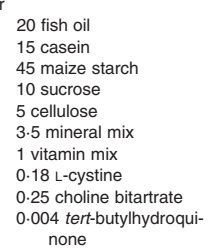 & 20 & 36 & $\mathrm{nr}$ & $\mathrm{nr}$ & $\mathrm{nr}$ & 10 & $0 \mathrm{v}$. other DIO diets & $\mathrm{nr}$ & $\begin{array}{l}\mathrm{d} v \text {. satllower- } \\
\text { seed oil } \\
\text { beet tallow }\end{array}$ & $\begin{array}{c}0 \text { v. other DIO } \\
\text { diets }\end{array}$ & $\mathrm{nr}$ & 23 \\
\hline & & 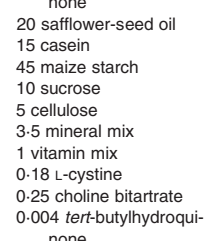 & 20 & 36 & & & & & $0 \mathrm{v}$. other DIO diets & $\mathrm{nr}$ & $\begin{array}{l}\text { iv bees tallow, } \\
\text { fish oil }\end{array}$ & $\begin{array}{c}0 \text { v. other DIO } \\
\text { diets }\end{array}$ & $\mathrm{nr}$ & \\
\hline & & 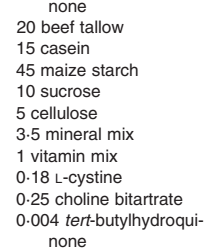 & 20 & 36 & & & & & $0 \mathrm{v}$. other DIO diets & $\mathrm{nr}$ & $\begin{array}{l}\text { iv. fish oil } \\
d v \text {. safflower- } \\
\text { seed oil }\end{array}$ & $\begin{array}{c}0 \text { v. other DIO } \\
\text { diets }\end{array}$ & $\mathrm{nr}$ & \\
\hline \multirow[t]{3}{*}{$\begin{array}{l}\text { Loh et al. } \\
\quad(1998)^{(104)}\end{array}$} & $\begin{array}{l}\text { Rats, Zucker, } \\
\text { genetically }\end{array}$ & g/100g & & & g/100g & & & & & & Total & & kcal & \\
\hline & & 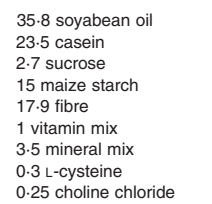 & 35.8 & 65 & 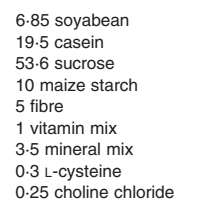 & 6.8 & 15 & 8 & 0 & $\begin{array}{l}0 \\
\text { dV palm olein } \\
\text { (only in } \\
\text { obese) }\end{array}$ & $\begin{array}{l}0 \\
\mathrm{~d} v \text {. palm olein } \\
\text { (conly in } \\
\text { obese) }\end{array}$ & $\mathrm{nr}$ & $i$ (only in obeses) & 24 \\
\hline & & 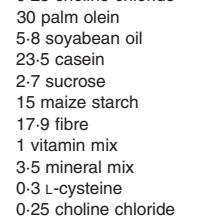 & 35.8 & 65 & & & & & $i$ (only in obesese) & $\begin{array}{l}\text { i (only in obese) } \\
\text { ivisoybaean } \\
\text { oil (only in } \\
\text { obeses) }\end{array}$ & $\begin{array}{l}\text { i (only in obese) } \\
\text { iv. soya- } \\
\text { bean oil } \\
\text { (only in } \\
\text { obese) }\end{array}$ & $\mathrm{nr}$ & $i$ (only in obeses) & \\
\hline $\begin{array}{l}\text { George et al } \\
(2000)^{(128)}\end{array}$ & $\begin{array}{l}\text { Mice, C57B/6J, } \\
\text { female, nr, }\end{array}$ & $g / 100 \mathrm{~g}$ & & & & & & & & & & & & \\
\hline
\end{tabular}




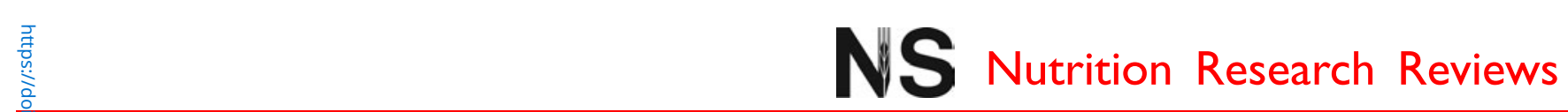

\begin{tabular}{|c|c|c|c|c|c|c|c|c|c|c|c|c|c|}
\hline & & Safflower-seed oil & 17.5 & $\mathrm{nr}$ & & & & & 00 cocaa butter & $\mathrm{nr}$ & - & $\mathrm{nr}$ & $\mathrm{nr}$ \\
\hline \multirow{2}{*}{$\begin{array}{l}\text { Harrold et al. } \\
(2000)^{(41)}\end{array}$} & $\begin{array}{l}\text { Rats, Wistar, male, } \\
110 \text {, }\end{array}$ & $\mathrm{g} / 100 \mathrm{~g}$ & & & & & & & & & Epididymal and & & $\mathrm{kJ}$ \\
\hline & & $\begin{array}{l}33 \text { Nestlé condensed milk } \\
7 \text { sucrose } \\
33 \text { ground pellet }\end{array}$ & 6.3 & 13 & $\begin{array}{l}\text { Standard pellet (CRM Bio- } \\
\text { sure, Cambridge, UK) } \\
\% \text { of total energy } \\
9 \text { fat } \\
65 \text { carbohydrate } \\
24 \text { protein }\end{array}$ & $4 \cdot 3$ & 9.2 & 8 & $\begin{array}{l}i \text { (high weight-gainers } \\
\text { only) } \\
0 \text { (low weight-gainers } \\
\text { only) } \\
i \text { (high v. low weight- } \\
\text { gainers) }\end{array}$ & $\begin{array}{l}\text { i (high weight-gai- } \\
\text { ners only) } \\
0 \text { (low weight-gai- } \\
\text { ners only) } \\
\text { i (high v. low } \\
\text { weight-gai- } \\
\text { ners) }\end{array}$ & $\begin{array}{l}\text { i (high v. low } \\
\text { weight-gai- } \\
\text { ners) }\end{array}$ & $\mathrm{nr}$ & $\begin{array}{c}\text { i (high v. low } \\
\text { weight- } \\
\text { gainers) }\end{array}$ \\
\hline \multirow[t]{2}{*}{$\begin{array}{l}\text { Ainslie et al. } \\
\qquad(2000)^{(39)}\end{array}$} & $\begin{array}{l}\text { Rats, Wistar, } \\
\text { female, } 223- \\
233 \mathrm{~g}, 20-22 \\
\text { weeks }\end{array}$ & & & & & & & & & & $\begin{array}{l}\text { Abdominal, } \\
\text { infrarenal } \\
\text { and subcu- } \\
\text { taneous }\end{array}$ & & $\mathrm{kJ}$ \\
\hline & & $\begin{array}{l}10 \text { ml fat emulsion (Intralipid; } \\
\text { Kabi Pharmacia, AB, } \\
\text { Stockholm) + non-puri- } \\
\text { fied laboratory diet (not } \\
\text { specified) }\end{array}$ & 20 & 36 & $\begin{array}{l}\text { Non-purified diet (not } \\
\text { specified) }\end{array}$ & 3 & 6.5 & 14 & $\mathrm{i}$ & $\mathrm{nr}$ & i & $\mathrm{nr}$ & $\mathrm{i}$ \\
\hline \multirow[t]{3}{*}{$\begin{array}{l}\text { Ghibaudide etal. } \\
(2002)^{(24)}\end{array}$} & $\begin{array}{l}\text { Rats, Sprague- } \\
\text { Dawley, male, } \\
50-60 \mathrm{~g}, \\
\text { weaning }\end{array}$ & $\%$ of total energy & & & $\%$ of total energy & & & & & & Total & & kcal \\
\hline & & $\begin{array}{l}45 \text { fat } \\
35 \text { carbohydrate } \\
20 \text { protein (D12451; } \\
\text { Research Diets, New } \\
\text { Brunswick, NJ, USA) }\end{array}$ & 26 & 45 & $\begin{array}{l}10 \text { fat } \\
70 \text { carbohydrate } \\
20 \text { protein } \\
\text { (D12450B; Research } \\
\text { Diets) }\end{array}$ & 4.6 & 10 & 26 & $\mathrm{i}$ & $\mathrm{i}$ & $\mathrm{i}$ & $\mathrm{nr}$ & $\mathrm{i}$ \\
\hline & & $\begin{array}{l}32 \text { fat } \\
51 \text { carbohydrate } \\
17 \text { protein (D12266; } \\
\text { Research Diets) }\end{array}$ & 17 & 32 & & & & & 0 & 0 & 0 & $\mathrm{nr}$ & 0 \\
\hline \multirow[t]{3}{*}{$\begin{array}{l}\text { Levin \& Dunn- } \\
\text { Meynell } \\
(2002)^{(82)}\end{array}$} & $\begin{array}{l}\text { Rats, Sprague- } \\
\text { Dawley (DIO } \\
\text { and DR), male, } \\
\text { DR: } 282- \\
327 \text {, DIO: } \\
368-402 \mathrm{~g}, \\
10-12 \text { weeks }\end{array}$ & $\mathrm{g} / 100 \mathrm{~g}$ & & & & & & & & & $\begin{array}{l}\text { Epididymal, ret- } \\
\text { roperito- } \\
\text { neal, perire- } \\
\text { nal and } \\
\text { mesenteric }\end{array}$ & & kcal \\
\hline & & $\begin{array}{l}8 \text { maize oil } \\
44 \text { sweetened condensed } \\
\text { milk } \\
48 \text { Purina chow (Purina Rat } \\
\text { chow, no. } 5008 \text { ) } \\
\text { \% of total energy } \\
31 \text { fat } \\
48 \text { carbohydrate } \\
21 \text { protein }\end{array}$ & $16 \cdot 6$ & 31 & $\begin{array}{l}\text { Purina chow (Purina Rat } \\
\text { Chow, no. 5008) }\end{array}$ & 4.5 & 9.6 & 10 & $\begin{array}{l}i(\text { Only in DIO) } \\
d v \text {. Ensure }{ }^{\circledast}\end{array}$ & $\begin{array}{l}i \text { (Only in DIO) } \\
d v \text {. Ensure }{ }^{\circledast}\end{array}$ & $\begin{array}{l}i \text { (Only in DIO) } \\
d v . \text { Ensure }{ }^{\mathbb{E}}\end{array}$ & $\mathrm{nr}$ & $\begin{array}{l}0 \\
d v . E^{2} \text { Esure }\end{array}$ \\
\hline & & $\begin{array}{l}\text { DIO diet + chocolate- } \\
\text { flavoured liquid diet } \\
\text { (Ensure } \\
\text { ducts Ross Pro- } \\
\text { ductsivison, Medical } \\
\text { Suplies Depot, AL, } \\
\text { USA) } \\
\text { \% of total energy } \\
22 \text { fat } \\
64 \text { carbohydrate } \\
14 \text { protein }\end{array}$ & 11.1 & 22 & & & & & i v. DIO diet & i v. DIO diet & i v. DIO diet & $\mathrm{nr}$ & i v. DIO diet \\
\hline \multirow[t]{2}{*}{$\begin{array}{l}\text { Levin \& Dunn- } \\
\text { Meynell } \\
(2002)^{(46)}\end{array}$} & $\begin{array}{l}\text { Rats, Sprague- } \\
\text { Dawley (DDO } \\
\text { and DR), male, } \\
300-45 \text { a nr }\end{array}$ & g/100g & & & & & & & & & Total & & \\
\hline & & $\begin{array}{l}8 \text { maize oil } \\
44 \text { sweetened condensed } \\
\text { milk } \\
48 \text { Purina chow (Purina Rat } \\
\text { Chow, no. } 5001 \text { ) } \\
\text { \% of total energy } \\
31 \text { fat } \\
48 \text { carbohydrate } \\
21 \text { protein }\end{array}$ & 16.6 & 31 & $\mathrm{nr}$ & $\mathrm{nr}$ & $\mathrm{nr}$ & 4 & i v. DR & $\mathrm{nr}$ & $i v \cdot D R$ & $\mathrm{nr}$ & $\mathrm{nr}$ \\
\hline $\begin{array}{l}\text { Ellis et al. } \\
\quad(2002)^{(53)}\end{array}$ & $\begin{array}{l}\text { Rats, Sprague- } \\
\text { Dawley, } \\
\text { female, } 61 \mathrm{~g}, 3 \\
\text { weeks }\end{array}$ & g/100 g & & & $g / 100 \mathrm{~g}$ & & & & & & Total, \% change & & kcal \\
\hline
\end{tabular}




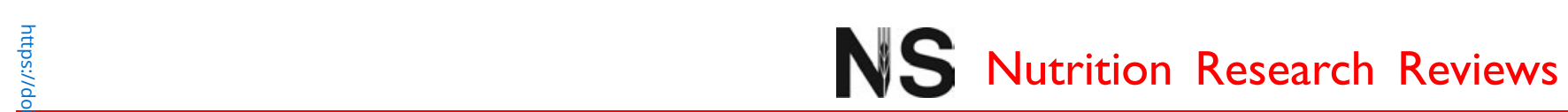

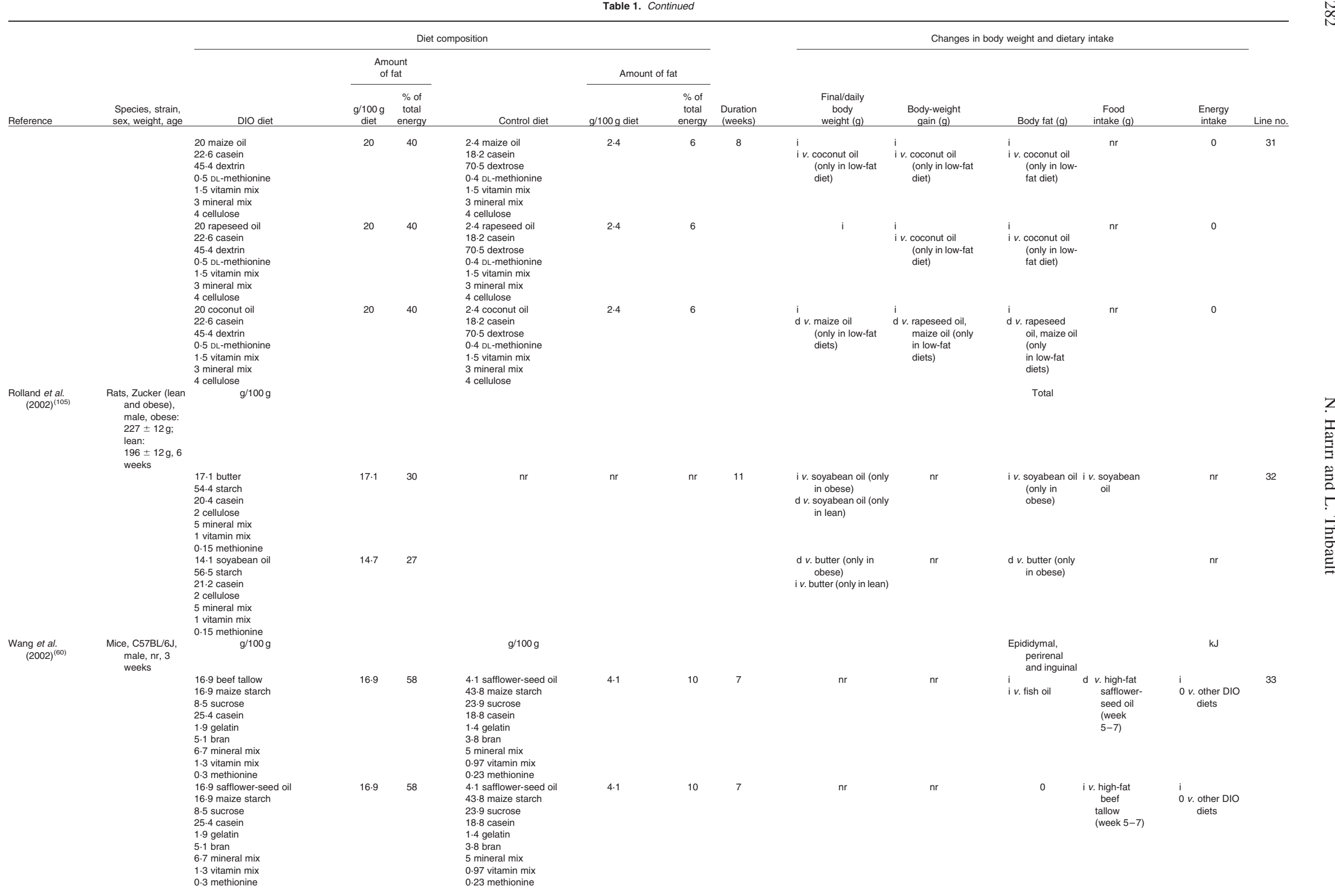



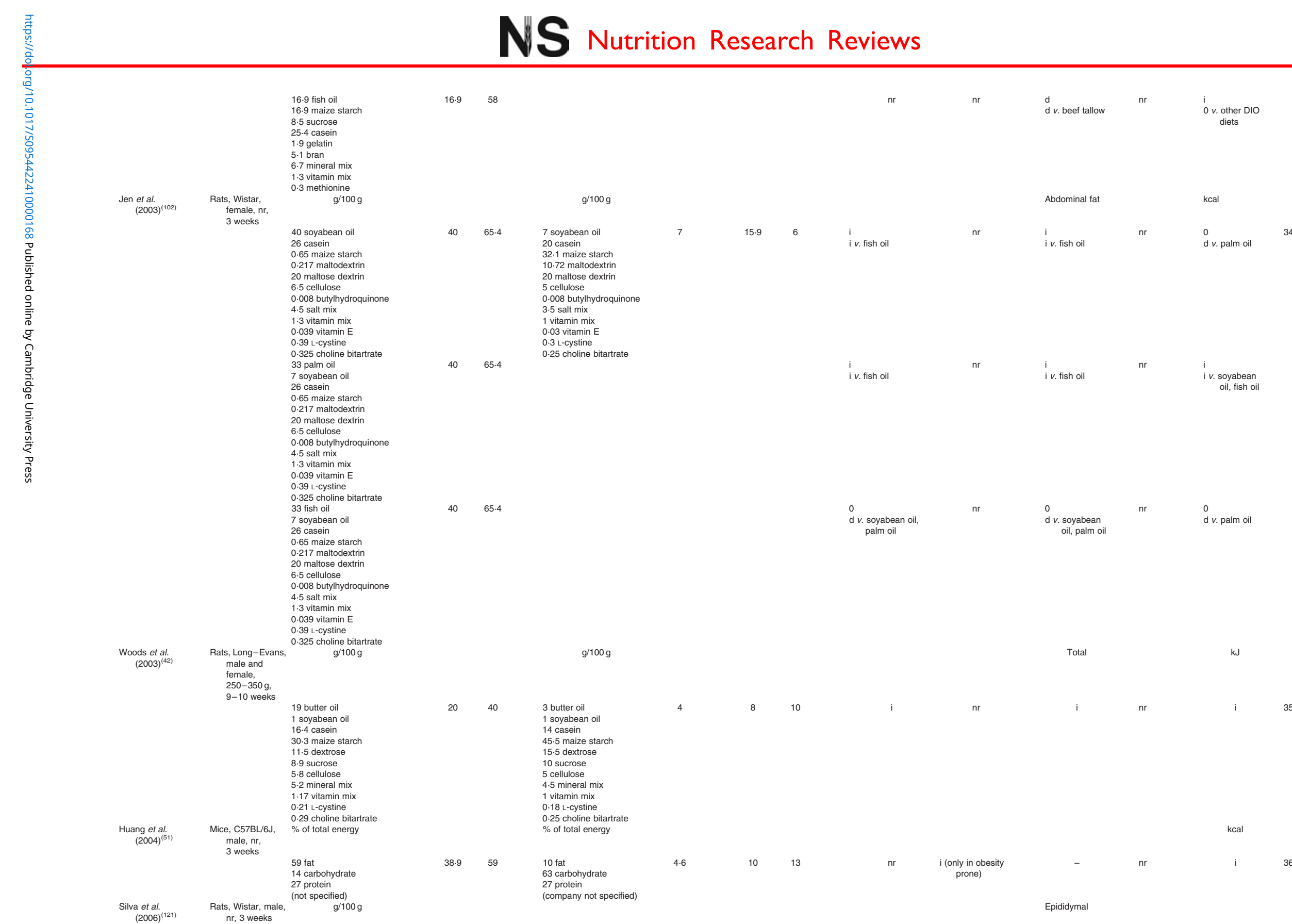


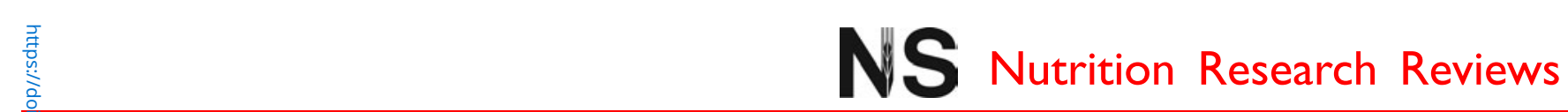

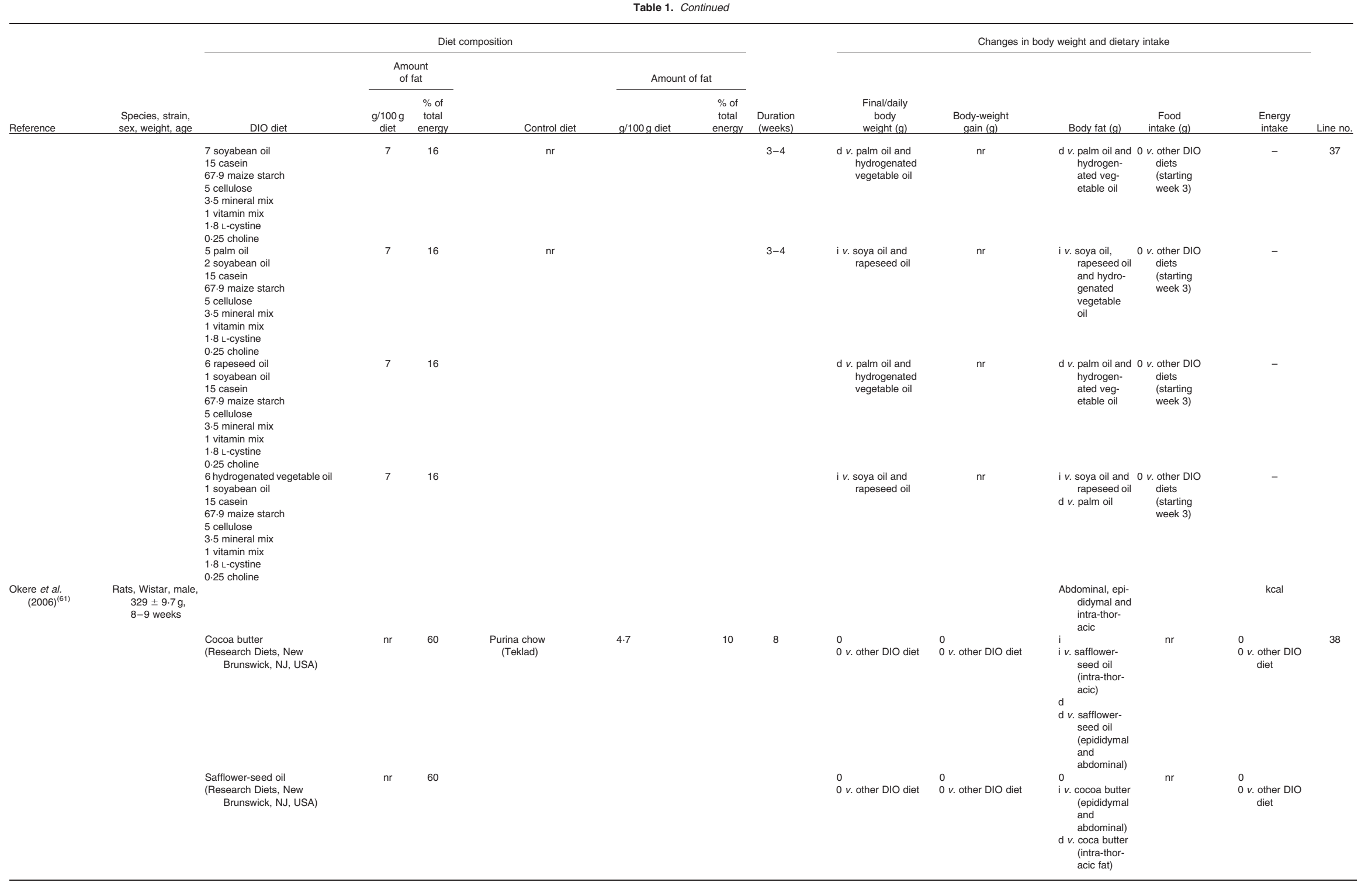


overweight adult female Wistar rats led to a lower final weight and fat mass in medium-chain fatty acid-fed animals $^{(131)}$. Similarly, lower body weight and fat gain were found in adult male Sprague-Dawley rats fed medium-chain TAG-rich high-fat diets (at $50 \%$ of energy) for 8 weeks than in rats fed high-fat diets based on longchain fatty acids ${ }^{(132)}$. Other studies in animals ${ }^{(133-135)}$ and in human subjects ${ }^{(13 \dot{6}, 137)}$ reported similar findings.

The location of the terminal double bond of PUFA may affect their action. Diets rich in $n-3$ fatty acids have been shown to prevent obesity better than other subclasses of PUFA $^{(56,116)}$. This effect has been reported in studies in human subjects ${ }^{(57,138,139)}$ mice $^{(48,60)}$ and rats ${ }^{(62,63,65,66,102)}$. In most of the animal studies lower fat deposition in subjects fed $n-3$ fatty acids was shown despite comparable food and energy intake among the $\operatorname{groups}^{(48,60,62,65,66)}$ (Table 1; lines 12, 33, 23, 22 and 14, respectively); therefore this effect can be related to the metabolic effects of $n-3$ fats. Suggested mechanisms involved in this effect of $n-3$ PUFA are: (1) low expression of lipogenic transcription genes with diets high in $n$-3 PUFA $^{(59,60,116,118)}$; (2) increased concentrations of thromboxane $\mathrm{A}_{2}$, leukotriene $\mathrm{B}_{4}$ and some cytokines that are elevated by an increase in $n-6$ PUFA intake and decrease in $n-3$ PUFA, and a low dietary $n-6: n-3$ ratio is beneficial for preventing them ${ }^{(140)}$; (3) inhibition of PG synthesis by $n-3$ PUFA leading to suppression of terminal differentiation of adipocytes ${ }^{(65)}$.

The configuration of the double bonds of PUFA may also affect the development of obesity. Conjugated fatty acids are PUFA that have at least one double bond separated by one single bond. Conjugated linoleic acid was shown to prevent obesity, and this effect has been attributed to: lower energy intake by decreasing the expression of neuropeptide $\mathrm{Y}$ and agouti-related protein, increased diet-induced thermogenesis, decreased pre-adipocyte differentiation via decreasing the expression of PPAR $\gamma$ which is a key factor for adipogenesis, and decreased lipogenesis through decreasing lipoprotein lipase activity and fatty acid synthase expression ${ }^{(141,142)}$. The antiobesity effect of conjugated linoleic acid was reported in studies conducted in rodents ${ }^{(143,144)}$ and human subjects ${ }^{(145,146)}$. However, animal $^{(147)}$ and human ${ }^{(148)}$ studies have found that feeding conjugated linoleic acid-rich diets might also lead to insulin resistance.

The studies mentioned varied in species, strain, age and/or sex of the animals used, which may explain some divergences among the results. Using different fats or fatty acids at various percentages of animal or plant origin and in a wide range of durations might have affected the results as well. For example, in a diet containing $40 \%^{(47)}$ or $58 \%{ }^{(60)}$ energy as beef tallow (48\% SFA and $52 \%$ PUFA), the percentages of SFA and PUFA would be 19 and $21 \%$ (in the $40 \%$ diet) and 28 and $30 \%$ (in the $58 \%$ diet), respectively. These percentages might have been high enough to reveal the obesogenic effect of SFA when used for a 7-8-week period. The source of fat (plant origin $v$. animal origin) also might have affected the results, for example, because SFA of plant origin might not be as effective as SFA of animal origin in developing obesity. Indeed, SFA of plant origin mainly contain medium-chain fatty acids (lauric acid in coconut oil and palm kernel oil) rather than long-chain fatty acids which are abundant in fats of animal origin ${ }^{(149)}$.

Taken together, the findings indicate that rats and mice are appropriate models for studying the effects of various fatty acids in developing obesity.

\section{Physiological mechanisms of high-fat diet-induced obesity}

\section{Food efficiency and diet-induced thermogenesis}

Some reports have attributed obesity induced by high-fat diets to their high food efficiency ( $\mathrm{g}$ body-weight gain per $\mathrm{kJ}$ food consumed). Energy from fat has a larger effect on body-weight gain than has energy from non-fat sources $(12,14,22,49,106,150,151)$. Diet-induced thermogenesis is the energy for digesting, absorbing and storing nutrients and produces a loss of energy for the body which is $2-3 \%$ for fats, $25-30 \%$ for proteins and 6-8\% for carbohydrates. Therefore, the efficiency of nutrient utilisation differs among macronutrients and fats have an efficiency of $97-98 \%$, whereas efficiency is $70-75 \%$ for proteins and $92-94 \%$ for carbohydrates ${ }^{(10,12,22,112)}$. In addition, it costs energy to build long-chain fatty acids from glucose or amino acids, whereas dietary fat contains long-chain fatty acid pre-formed.

\section{Energy density}

Some studies have shown that a fat-rich diet induces obesity by increasing energy intake ${ }^{(24,38,39,41,42)}$. If weight of intake is not increased at least in proportion, this implicates the high energy density of high-fat diets.

Individuals with ad libitum access to diets with different energy densities ate the same amount of food by weight (in a meal or over a few days $)^{(72,152-155)}$. On the other hand, after 2 weeks of exposure, subjects learned to compensate for the higher energy density of the diet, and ate less weight of food $^{(156)}$. Rats and mice have been labelled as hyperphagic when fed a fat-rich diet, which was based on animals ingesting more energy and not necessarily weight of food $^{(24,39,42,51)}$. Although in the mentioned studies, the wieght of food ingested was not always reported, rats might have attempted to adjust their intake according to the energy density of the fat-rich diet. While some of the high-fat diets were less dense in other macronutrients and micronutrients, rats could not fully adjust for the extra dietary energy while ingesting a minimal amount of the high-fat diet to meet their requirements (for example, $5 \%$ protein for maintenance and $15 \%$ for growth) ${ }^{(157)}$ with carrying extra energy. Therefore, high-fat diets used to induce obesity in animal models should meet macronutrient and micronutrient requirements of the animals, so that hyperphagia can be better interpreted.

\section{Satiating effects of fat}

Weaker satiety signals from fat than from carbohydrates and proteins have been suggested to play a role in overconsumption of energy from fat-rich diets ${ }^{(69,70,158,159)}$. To clarify if the hyperphagia from fat-rich diets is due to their post-ingestive effect, rats were administered by gastric self-infusion for $16 \mathrm{~d}$ isoenergetic high-fat $(59.9 \%$ of 
energy) and high-carbohydrate (fat: $16.7 \%$ of energy) liquid diets $^{(160)}$. Rats self-infused more energy per $d$ of the high-fat diet than of the high-carbohydrate diet; thus, when orosensory effects are minimised, hyperphagia on high-fat diets remains. Poorly satiating post-ingestive effects of fat produced more frequent meals and resulted in large meals $^{(160)}$

Post-ingestive effect of nutrients also may increase food intake by conditioning sensory preference ${ }^{(159)}$. In a $9 \mathrm{~d}$ study, adult female Sprague-Dawley rats were infused intragastrically with isoenergetic high-fat $(59.6 \%$ of energy) and high-carbohydrate (14.6\% of energy) diets paired with different flavours (cherry, grape or strawberry). The rats drank substantially more $(38 \%)$ of the solution paired with the infusion of the high-fat diet than the solution paired with the infusion of the high-carbohydrate diet, hence the post-ingestive effect of the diets high in fat enhances preference for the sensory features of high-fat diets ${ }^{(159)}$.

Various mechanisms have been suggested for a reduction in satiety signals with high-fat feeding and attenuation of suppression of energy intake by high-fat diets. These include: (1) attenuated enterogastric inhibition of gastric emtpying and secretion of satiety hormones (cholecystokinin, peptide YY (PYY) and glucagon-like peptide-1) which are normally stimulated by the presence of fat in the small intestine, and thus decrease late satiety ${ }^{(161,162)}$; (2) inhibition of fatty acid oxidation ${ }^{(163,164)}$, so that high-fat diets lower the rate of oxidation of fatty acids, hence they may increase intake; (3) insensitivity to the food intake reducing the effect of apoA-IV, which is a peptide that decreases meal size ${ }^{(165,166)}$. Low-energy-dense diets have greater volume and so induce more stomach distension than diets with higher energy density ${ }^{(13)}$.

\section{Hormones}

Signals from adipose tissue (leptin, adiponectin and resistin), stomach (ghrelin and obestatin), pancreas (insulin) and intestine (cholecystokinin, PYY and incretins including glucagon-like peptide-1 and gastric-inhibitory peptide) are sent to the brain to regulate energy balance ${ }^{(167-169)}$. The present review reports the most extensively studied hormonal effects on energy balance (by reducing energy expenditure or increasing energy intake) associated with high-fat feeding.

Leptin. Leptin, first identified in 1994 by Rockefeller University scientists, is an important hormone in the control of food intake and body weight ${ }^{(170)}$. It is as an obese gene product produced by adipose tissue, generally in proportion to fat mass, with rises in plasma levels resulting in a decrease in food intake and increase in energy expenditure ${ }^{(170-174)}$. Plasma leptin levels display a circadian rhythm. In humans, leptin is increased during the night and peak values are reached at about 24.00 hours, while minimum values are found at midday ${ }^{(175,176)}$. Studies in human subjects have shown that obesity is associated with higher concentrations of plasma leptin ${ }^{(176)}$. Moreover, in healthy men, leptin levels increased in response to a high-fat meal; however, no differential effects among fatty acid chain length or saturation were reported ${ }^{(177)}$.
Laboratory rats have similar circadian variations of plasma leptin, although maximum levels are reached in the middle of their active phase (at night) and minimum levels in the middle of their resting phase (daytime) ${ }^{(178,179)}$. In a study in weanling male and female normal FVB mice, 12 weeks of feeding a high-fat diet (Western diet, Teklad Adjusted Calories Western-Type Diet, no. 88187 , fat at $40 \%$ of total energy; Harlan-Teklad, Madison, WI, USA) produced 2.6- to 4.6-fold elevation in plasma leptin levels (measured between 09.00 and 11.00 hours) relative to control mice fed chow, but intake of energy was not less than that of the chow-fed controls ${ }^{(180)}$. Higher leptin levels were also found after a $2 \mathrm{~h}$ high-fat meal at dark onset compared with pre-meal levels in adult male obesity-prone Sprague-Dawley rats ${ }^{(181)}$.

In adult male Osborne-Mendel rats, adapted to a high-fat diet (56\% of energy) for 2 weeks, no reduction in food intake at 2, 4, 6 and $24 \mathrm{~h}$ following intraperitoneal injection of leptin $(0.5 \mathrm{mg} / \mathrm{kg}$ body weight $)$ after an overnight fast was found $^{(182)}$. In contrast, when the rats had been adapted to a low-fat diet, the injection suppressed the food intake at all time points. Thus, the intake response to peripheral leptin was impaired by chronically high levels of fat intake ${ }^{(182)}$. Harrold et al. ${ }^{(41)}$ found hyperleptinaemia after 1 week of feeding adult male Wistar rats a raised level of energy as fat (13\% of energy). Levin \& Dunn-Meynell ${ }^{(46)}$ showed that when adult male Sprague-Dawley rats were fed a high-fat diet ( $31 \%$ of energy) for 1 week and were then switched to 3 weeks of chow feeding, leptin levels (time of sampling not mentioned) were higher in rats that were prone to developing obesity on the high-fat diet than in rats that were resistant to dietary obesity despite having comparable body weights. Both obesity-prone and -resistant SpragueDawley rats fed high-fat diets (at $20 \%$ of total energy) showed resistance to the anorectic effect of centrally administered leptin $(10 \mu \mathrm{g}$; intracerebroventricular; ICV), while control animals fed a low-fat diet (3\% of total energy) decreased their energy intake following leptin administration ${ }^{(95)}$. However, in another study resistant animals did not show compromised responsiveness to the food-lowering effect of leptin when fed high-fat diets ${ }^{(183)}$. Overall, these results indicate that high-fat feeding induces hyperleptinaemia and leptin resistance and that this effect is independent of obesity-induced leptin resistance.

The mechanism thought to be involved in hyperleptinaemia and leptin resistance on the high-fat diet involves hypothalamic leptin receptors and their signalling pathways ${ }^{(180)}$. Animals susceptible to dietary obesity have reduced hypothalamic leptin receptor gene expression and show an early leptin response to an increase in dietary fat ${ }^{(184)}$.

In contrast to this, Ainslie et al. ${ }^{(39)}$ showed that female hooded Wistar rats aged between 20 and 22 weeks fed a high-fat diet ( $36 \%$ of energy) for 4 weeks had significantly lower plasma leptin levels (measured after an overnight fast) than control rats fed low-fat diets $(6.5 \% \text { of energy })^{(39)}$. A more recent study showed that adult male SpragueDawley rats fed a high-fat diet (60\% of energy) for 2 weeks were hypersensitive to the food intake-lowering effect of ICV administration of leptin $(3 \mu \mathrm{g})$; however, after 5 weeks on the high-fat diet, rats became insensitive to this effect of injected leptin ${ }^{(185)}$. Another study in weanling C57BL/6J 
mice led to similar conclusions ${ }^{(186)}$. The researchers suggested that early in high-fat feeding, animals are sensitive to the food-lowering effect of leptin but despite the reduction in food intake animals become fat as a result of the increase in food efficiency, leading to an increase in plasma leptin levels that is followed by insensitivity to its action $^{(186)}$. This implies that leptin resistance after longterm feeding on a high-fat diet is an effect of the obese state rather than the cause of obesity development.

Animal studies found that the fatty acid composition of a high-fat diet may influence leptin levels in the circulation. Lower serum leptin levels (measured 3-6 h after initiation of the dark phase) were found in 8-week-old lean male Wistar rats fed a diet rich in long-chain SFA (cocoa butter at $60 \%$ of energy) than in animals fed a diet rich in long-chain PUFA (safflower-seed oil at the same percentage) or chow for 8 weeks ${ }^{(61)}$. Although total body fat was similar across dietary groups, SFA-fed rats had less abdominal and epididymal fat, and more intrathoracic fat compared with the other groups. Another study found that adult male Sprague-Dawley rats fed a beef tallow-based diet for 10 weeks had lower leptin levels than animals fed safflowerseed or fish oil, while fish oil-fed animals had the lowest amount of perirenal fat ${ }^{(62)}$. These studies suggest that the site of fat accumulation depends on the fatty acid profile of the diet, and various adipose tissue depots can differently contribute to circulating leptin. However, no differences were found between moderate-SFA and -MUFA beef tallow, high-PUFA safflower-seed oil and high- $n-3$ PUFA fish oil in the increased fasting leptin levels in adult male SpragueDawley rats fed these diets for 10 weeks $^{(187)}$. Greater leptin levels were found in weanling C57BL/J6 male mice fed high-fat diets (at $58 \%$ of energy) based on beef tallow for 7 weeks than mice fed high-fat diets based on fish oil, safflower-seed oil or animals fed low-fat diets (at $10 \%$ of energy); leptin levels were correlated with body fat as well $^{(60)}$. Similar results were found in other studies $(102,188)$.

Ghrelin. Ghrelin is a peptide released by cells in the fundus of the stomach that stimulates the release of growth hormone from the pituitary and was identified by Kojima et al. in $1999^{(189)}$. Ghrelin rises before and falls after each ad libitum meal and increases food intake ${ }^{(190,191)}$. In humans ghrelin levels peak in the morning (08.00 hours), at noon (12.00 to 13.00 hours) and in the evening (17.00 to 19.00 hours) and fall after each peak ${ }^{(192)}$. Obese individuals have lower fasting ghrelin levels than lean individuals and reduced suppression of ghrelin secretion after a meal ${ }^{(193-196)}$. A fatrich meal has a smaller suppressive effect on plasma ghrelin concentration than a carbohydrate-rich meal regardless of obesity status ${ }^{(197)}$. So far, no effect of dietary fatty acid profile on total ghrelin levels has been reported ${ }^{(177,198)}$

In rats there is a peak of plasma levels of ghrelin $5 \mathrm{~h}$ after light onset (resting phase) which remains relatively high for $9 \mathrm{~h}^{(178)}$. There is also a second rise just before the beginning of the dark phase, followed by a sharp drop and then a gradual rise during the remainder of the dark phase ${ }^{(199)}$. Ghrelin gene expression and plasma ghrelin concentrations have been found to be lower in mice with dietary obesity than in their lean counterparts, coupled with a decrease in sensitivity to the orexigenic effects of ghrelin as well as impairment in suppression of ghrelin in response to a meal $^{(200,201)}$. A study was conducted by Liu et al. ${ }^{(202)}$ in two strains of rats with different susceptibilities to develop obesity (Osborne-Mendel prone and S5B/P1 resistant) fed a diet high in fat ( $56 \%$ of energy) for 2 weeks. Ghrelin gene expression was increased in the stomach of fasted susceptible rats but plasma ghrelin concentrations remained unchanged, while in resistant rats both expression and plasma levels of ghrelin remained unchanged. This indicated that ghrelin may play a role in susceptibility to dietary obesity. In adult Long-Evans rats, 2 weeks of highfat feeding ( $70 \%$ of energy) was associated with lower levels of ghrelin than was feeding on a high-carbohydrate $\operatorname{diet}^{(203)}$. In an attempt to distinguish between the effects of a high-fat diet and of dietary obesity on ghrelin concentrations, Greeley et al. ${ }^{(204)}$ fed adult male Sprague-Dawley rats high- (45\% of energy) or low (12\% of energy)-fat diets for 3 weeks. Both groups were tested with triiodothyronine $\left(\mathrm{T}_{3}\right)$ to prevent accumulation of fat. Decreased ghrelin levels in high-fat-fed animals were not restored by $\mathrm{T}_{3}$ treatment, despite the fact that the groups had comparable weights. Moreover, duodenal and jejunal infusion of fat suppressed plasma ghrelin less than glucose and amino acids in adult male Sprague-Dawley rats ${ }^{(205)}$

The mechanisms suggested for ghrelin's actions are twofold. It stimulates hypothalamic secretion of neuropeptide $\mathrm{Y}$ that increases food intake, decreases fat oxidation and utilisation of fat and plays a role in meal initiation ${ }^{(190,203)}$. Ghrelin also decreases the utilisation of fat ${ }^{(191)}$. High-fat diets are known to down-regulate ghrelin secretion ${ }^{(200,203)}$ and an inverse relationship between leptin and ghrelin has been reported ${ }^{(203)}$. On the other hand, hypothalamic expression of ghrelin receptors was enhanced and ghrelin levels were greater in adult male Wistar rats fed a fat-rich meal $^{(206)}$. Thus, regulation of ghrelin concentration through fat intake remains inconclusive.

Since suppression of ghrelin levels after a meal is associated with postprandial satiety, the lower suppression of ghrelin secretion following high-fat diets might be an explanation for hyperphagia on high-fat diets. Thus, in an environment with abundant high-fat foods, impairment of ghrelin suppression after a meal leads to overconsumption of energy and induces obesity. Furthermore, the obesity itself impairs the suppression of ghrelin secretion after a meal which further exacerbates the development of obesity.

Insulin. Obesity is associated with elevated basal plasma insulin levels and resistance to the metabolic effects of insu$\operatorname{lin}^{(77,207)}$. Independent of obesity, high-fat feeding itself contributes to impaired glucose tolerance and insensitivity to the blood glucose-lowering effect of insulin ${ }^{(207,208)}$. The fatty acid profile of the diet plays a crucial role in insulin resistance dependent on a high-fat diet ${ }^{(207-209)}$. In a human study, intake of SFA and MUFA was positively correlated with plasma levels of glucose and insulin ${ }^{(210)}$. Replacing SFA with MUFA had no beneficial effect on blood glucose and insulin levels during 4 weeks of high-fat feeding in adult overweight and obese men ${ }^{(119)}$. On the other hand, some studies have shown beneficial effects of MUFA intake on glucose homeostasis and insulin sensitivity ${ }^{(211)}$. 
Animal studies have also shown that hyperinsulinaemia and insulin resistance are induced by high-fat feeding $^{(42,166,212)}$. In female C57BL/6J mice fed high-fat diets (at 10, 20, 30, 40, 50 and $60 \%$ of total energy) for 15 weeks, a linear relationship between the percentage of dietary fat and glucose intolerance was found ${ }^{(26)}$. This dose-dependent effect was also seen in weanling male Sprague-Dawley rats fed diets with different percentages of energy as fat $(10,32,45 \%)^{(24)}$.

Mechanisms of the hyperinsulinaemia and insulin resistance with high-fat diets and obesity are discussed in reviews by Lichtenstein \& Schwab ${ }^{(207)}$, and Riccardi et al. ${ }^{(208)}$. These authors suggest that decreases in insulin receptors, glucose transport and metabolism are involved, plus reduction in liver and muscle glycogen synthase activity and storage of glucose as glycogen ${ }^{(207,208)}$. These abnormalities thus develop when the intake of fat is more that $40 \%$ of total energy. Excessive amounts of adipose tissue (hypertrophy and hyperplasia) stress the endoplasmic reticulum, resulting in secretion of cytokines and decrease in the responsiveness of the cells to insulin ${ }^{(77)}$.

Differences among dietary fatty acids affect the composition of the cell membranes and this in turn influences the affinity of receptors for insulin and so its action on the cell ${ }^{(207,208,213)}$. Some studies have found that insulin secretion and sensitivity are enhanced as the degree of unsaturation of fatty acids increases, especially with $n-3$ feeding, and thus feeding diets rich in SFA results in more insulin resistance than MUFA and PUFA ${ }^{(116,207,208,213)}$. In a study in 7-week-old female C57BL/6J mice fed high-fat diets (60\% of energy) composed of palm oil, lard, fish oil, perilla oil or rapeseed oil for 18 weeks, blood glucose levels were higher in all the high-fat-fed animals 30, 60 and 120 min after an oral glucose challenge than in the group fed a high-carbohydrate-low-fat diet (fat: $11 \%$ of energy), but the increase in fasting blood insulin levels was only reliable in the group fed palm oil ${ }^{(52)}$. In weanling female Wistar rats, no difference in insulin levels was found between soyabean oil and palm oil groups ${ }^{(102)}$, whereas lower plasma insulin levels were found in adult male Wistar rats fed a high-fat diet (60\% of energy) rich in SFA (cocoa butter) than in the control animals $\left(10 \%\right.$ of energy) ${ }^{(61)}$. These disparities might be related to different fats used in these studies: palm oil and cocoa butter differ in SFA content and so diets will vary in SFA at the different percentages of total energy used in the studies. The same can be said for lard, soyabean oil and safflower-seed oil. Beneficial effects of $n$-3 PUFA on action of insulin are reported in many studies ${ }^{(52,62,214,215)}$.

Since human and animal studies have shown comparable relationships of hormones to obesity, these models can be used to clarify the uncertain areas such as effects of fatty acid profile of the diet on these hormones. However, relating hormone action to obesity itself requires demonstration of its effect on energy intake and/or expenditure.

\section{Behavioural mechanisms of high-fat diet-induced obesity}

As discussed in the previous sections, one explanation why high-fat diets induce obesity is hyperphagia ${ }^{(24,38,39,41,42)}$, i.e. increased weight or volume of daily dietary intake.
Effects of energy density were reviewed earlier. A possible lack of inhibitory effects of fats on intake ('satiety') was discussed above. Here the intake-facilitatory effects of sensory characteristics (or palatability) of high-fat diets will be considered ${ }^{(13,22,69,70)}$. Feeding rhythmicity ${ }^{(216,217)}$, social environment ${ }^{(5,218-228)}$ and stress ${ }^{(229-231)}$ may also promote obesity. Each of these will be reviewed below. Because social environment is not documented in relation to high fat intake, only feeding rhythmicity and stress will be reviewed below.

\section{Sensory facilitation of intake}

Facilitation of intake by the sensory characteristics of highfat foods is an important influence on ingestion. Sensory stimulation from food consumption can influence energy intake directly ${ }^{(232)}$, by promoting selection, consumption, digestion and absorption of a food ${ }^{(233)}$. It also increases diet-induced thermogenesis ${ }^{(234,235)}$. Foods high in fat are usually preferred by rats to those that are low in fat and are consumed in greater amounts as a result ${ }^{(13,70,156,236)}$. A variety of sensory properties contribute to this high palatability of fat-rich diets, mainly texture and odour $^{(69,160,237,238)}$.

In a study on adult male Long-Evans rats, Warwick \& Weingarten ${ }^{(160)}$ compared the sensory effects of a high-fat $(59.9 \%$ of energy) and a high-carbohydrate diet (fat at $16.7 \%$ of energy). In order to minimise the post-ingestive effect of diets on intake, they used a preparation in which most of the ingested liquid food drained out of the stomach via a fistula. When both diets were offered simultaneously, rats consumed more of the high-fat diet than the highcarbohydrate diet, demonstrating a sensory preference. Warwick et al. ${ }^{(238)}$ concluded from a study in weanling female Sprague-Dawley rats that consuming high-fat diets early in life can lead to a sensory preference for this fat product which is relatively stable.

Evidence for sensory preferences for fats in rat and mouse animal models is likely to be based on NEFA released from the TAG in food ${ }^{(239,240)}$. Lingual lipase has such activity in rodents; taste receptor cells in the oral cavity of rats can easily detect these NEFA; these gustatory signals are transmitted to the brain where they cause release of neurotransmitters such as dopamine and endorphin ${ }^{(239-241)}$. Long-chain PUFA stimulate T-cell receptors more efficiently and thus are more strongly preferred than other types of fatty $\operatorname{acid}^{(241)}$. Preference for fat is also found in humans, with textural, olfactory and gustatory cues being involved $^{(242)}$.

\section{Rhythmicity of feeding}

Rhythmicity in feeding (variation over time in total amount ingested, size and frequency of meals) may play a role in the development of obesity. In human subjects, a lower risk of obesity was reported in both adults and children with a high frequency of eating episodes ${ }^{(216,217,243)}$. A greater number of meals each day was consumed by obese women than healthy-weight women in Sweden in a cross-sectional survey ${ }^{(244)}$. However, similar meal patterns were found in 
obese and healthy-weight Swedish men in a dietary survey ${ }^{(245)}$.

Time of eating also may play a role in the development of obesity. In humans, meals eaten late in the evening have been suggested to be one of the risk factors of obesity $^{(217,246)}$. In free-living individuals food intake in the morning was more satiating and associated with less overall intake throughout the day than evening food ${ }^{(5)}$. However, in another study, percentage energy from evening food intake and weight changes were unrelated ${ }^{(247)}$. Taylor et al. ${ }^{(248)}$ and Bellisle ${ }^{(249)}$ suggested that the effects of meal patterns on human obesity have yet to be clarified.

Unlike humans, rats are nocturnal animals that ingest 70$80 \%$ of their food during the dark phase ${ }^{(250)}$. There are two peaks in meal frequency and rate of intakes: at the beginning of the night and towards the end, i.e. dusk and dawn feeding ${ }^{(251,252)}$. In adult male Wistar rats fed a stock diet containing $10 \%$ energy as fat, the greater intake during the dark phase resulted in positive energy balance and fat deposition, with negative energy balance along with the oxidation of fat in the light phase over fourteen $24 \mathrm{~h}$ cycles $^{(250,253)}$. Altered circadian rhythmicity of intake characterised by larger meal size and decreased meal frequency has been found in genetically obese animals fed non-purified diets ${ }^{(252,254-257)}$.

Some animal studies have found a relationship between sizes of meals and susceptibility to obesity. Adult male Sprague-Dawley rats that ingested chow in larger meals had a higher rate of weight gain when fed high-fat diets than rats that were fed on chow in smaller meals ${ }^{(258)}$. When weanling male obesity-prone Sprague-Dawley rats were fed high-fat diets ( $45 \%$ of energy) for 19 weeks, they ate larger meals than resistant animals ${ }^{(259)}$. In adult inbred obesity-prone and -resistant rats fed chow, on the other hand, the obesity-prone rats ingested smaller meals more frequently ${ }^{(260)}$. These results suggest that an irregular meal pattern is not a cause of developing obesity in obesity-prone animals. A $6 \mathrm{~h}$ meal pattern analysis during the dark phase in adult male Sprague-Dawley rats exposed to isoenergetic high- and low-fat diets (soya oil at 38 and $10 \%$ of total energy) for 2 weeks revealed comparable amounts of food ingested in the first meal, but less food ingested in the second and third meal of high-fat-fed rats, as well as greater meal frequency, shorter inter-meal interval (IMI) and lower rate of weight gain than animals fed the low-fat diet ${ }^{(261)}$ However, when feeding period was prolonged to 8 weeks, the size of the second meal and IMI increased. Increased meal size and decreased meal frequency have also been found in rats acclimatised to a mixture of high-fat and high-carbohydrate diets (providing $38.5 \%$ energy as fat) for $14 \mathrm{~d}$ and then fed a fat-rich diets (at $60 \%$ of total energy) for an additional $8 \mathrm{~d}^{(262)}$.

There is a shift of food intake from the dark phase to the light phase in genetically obese rats and mice ${ }^{(254-256)}$. Mistlberger et al. ${ }^{(263)}$ reported higher weight gain in genetically obese Zucker rats when fed ad libitum than in those fed only during the $14 \mathrm{~h}$ dark phase, while both groups had similar food intakes. In addition, rats differ in their macronutrient selection during the light-dark cycle. It has been reported that when rats are offered a two- or three-way selection between macronutrients, they eat more carbohydrate at the beginning of the dark phase, and more protein and fat at the end of the dark phase and during the light period ${ }^{(264)}$. Thus it is probable that, with high-fat feeding, more food will be ingested in the light period that may further facilitate the development of obesity.

Obesity-prone rats respond more than resistant animals with an increase in meal size. This might account for the hyperphagia with high-fat feeding in dietary obesity. Further research is needed to find out the cause-effect relationship between eating patterns and obesity.

\section{Stress}

Many studies have shown that long-term stress increases food intake and promotes weight and fat gain in human subjects ${ }^{(265,266)}$. In addition, obesity was found to be associated with depression ${ }^{(267)}$. Higher levels of obesity in depressed individuals as well as higher prevalence of depression in overweight and obese women and extremely obese men $\left(\mathrm{BMI} \geq 40 \mathrm{~kg} / \mathrm{m}^{2}\right)$ were found ${ }^{(268,269)}$. Depressed individuals with eating disorders often describe themselves as chronically stressed and usually are obese, suggesting that they eat more when stressed in an attempt to cope with the situation and feel better ${ }^{(230)}$. Energy-dense foods with high fat and sugar are known as 'comfort food' and are more often eaten during stress ${ }^{(229,266,270)}$. On the other hand, some individuals show loss of appetite during stress ${ }^{(271)}$. It has been suggested that this difference is based on the dieting history of the individual: usually dieters increase and non-dieters decrease their intake while in a stressful situation $^{(271)}$.

A different pattern of responsiveness to stress has been shown in a variety of rodent models ${ }^{(99,272-274)}$. Rowland \& Antelman $^{(274)}$ discovered that in adult female SpragueDawley rats mild stress induced by six daily sessions (10-15 min) of pinching of the tail for $5 \mathrm{~d}$ at equal intervals while they had free access to sweetened milk and tap water resulted in greater food intake and body-weight gain than in the control animals. However, chronic exposure of adult male Sprague-Dawley rats to an immobilisation stressor led to a decrease in food intake, independent of the duration of the stress, while handling stress did not result in change in food intake ${ }^{(273)}$.

Obesity-prone and -resistant animals are also different in their responsiveness to stress. A study was conducted by Levin et al. ${ }^{(272)}$ in 2.5-month-old selectively bred male obesity-prone and -resistant Sprague-Dawley rats fed a high-fat diet (31\% of energy) for 1 week. They were then randomly assigned to a stress group or control group while fed the high-fat diet for 3 weeks and then the high-fat diet plus Ensure ${ }^{\circledR}$ (Ross Products Division, Medical Supplies Depot, AL, USA) for another 2 weeks. Rats in the stress group had daily exposure to different stressors for 5 weeks, which were restraint for $15 \mathrm{~min}$, moving the animal to the cage of another, exposure to another male rat for $10 \mathrm{~min}$, 2 min swimming or saline injection. Results showed that stressed obesity-resistant rats gained less weight without any decrease in energy intake with little effect of the stressors on body-weight gain and energy intake of obesityprone animals. Adding Ensure ${ }^{\circledR}$ to the high-fat diet increased energy intake and rate of weight gain in resistant 
animals, but cumulative weight gain over 5 weeks was still lower in stressed rats than in control animals. Weight gain and intake of the obesity-prone rats were unaffected by the addition of Ensure ${ }^{\circledR}$. It was suggested that resistant rats had a lowered sympathetic activity compared with their unstressed controls, which was shown by lower noradrenaline levels in their urine.

The effect of a high-fat diet on weight gain after stress was investigated in a study in 3- to 4-month-old male obesity-prone and -resistant Sprague-Dawley rats that were restrained once for $20 \mathrm{~min}$, and after release were presented either a high-fat diet (at $31 \%$ of energy) or chow for $9 \mathrm{~d}^{(99)}$. Stressed prone rats fed the high-fat diet gained more weight than unstressed prone rats fed the same diet while having similar food intakes. However, when stressed prone rats were fed chow, they gained less weight than unstressed prone rats fed the same diet. These results showed that prone rats were less responsive to the weight-reducing effect of immobilisation stress when fed a high-fat diet; at the same time they were more responsive to this effect when fed chow. Immobilisation stress had no effect on body-weight gain in resistant rats fed either $\operatorname{diet}^{(99)}$. In another study, adult male Sprague-Dawley rats fed high-fat (at $40 \%$ of total energy) or low-fat diets (at $12 \%$ of total energy) for $4 \mathrm{~d}$ were divided into two groups of stressed (restraint tubes with no food and water access followed by tail blood sampling, $3 \mathrm{~h}$ daily for three consecutive days) and mildly stressed rats (moved to new cages, food and water deprived for the same period and blood sampled) ${ }^{(275)}$. On the days of restraint, stressed rats lost weight regardless of the diet. High-fat-fed mildly stressed animals stopped gaining weight; however, low-fat-fed mildly stressed rats gained weight throughout the experiment ${ }^{(275)}$. Results showed that low- and high-fat diets resulted in similar body-weight changes under a severe stress, whereas with a mild stress high-fat-fed animals were more responsive to the weightlowering effect of stress. In adult male Long-Evans rats, the weight loss resulting from chronic stress was regained after recovery from stress and body-weight and fat gain were greater in high-fat-fed rats than in chow-fed control animals $^{(276)}$. Higher preference for high-fat feeding during chronic stress was reported in mice ${ }^{(277)}$.

Mechanisms that influence food intake during acute and chronic stress are different. Physiologically, the initial response of the body to an acute stress is secretion of corticotrophin-releasing factor from the paraventricular nucleus of the hypothalamus that stimulates the secretion of adrenocorticotropin hormone from the anterior pituitary which in turn leads to the release of cortisol from the adrenal cortex to provide energy for the brain and/or muscles. Then cortisol itself makes a negative feedback for its further secretion. However, with a chronic exposure to stressor, the negative feedback does not work efficiently and thus induces an increase in food intake and body-weight gain through increased secretion of glucocorticoids which elevate appetite, food intake and fat storage especially in the abdomen ${ }^{(230,231,278)}$. In adult male Wistar rats, a chronic stress of keeping rats in cages filled with water to a height of $2 \mathrm{~cm}$ for $5 \mathrm{~d}$ led to delayed gastric emptying during the first $24 \mathrm{~h}$ of exposure, but after that it was accelerated and exceeded that of the control group by day 5. In addition, catecholamines were increased during the first $24 \mathrm{~h}$ and then decreased while active ghrelin levels were high on day 3 and remained elevated until day $5^{(279)}$. It was suggested that the increased sympathetic activity after $24 \mathrm{~h}$ stimulated ghrelin secretion, and therefore the increased food intake found during chronic stress might be a result of enhanced plasma ghrelin. Plasma ghrelin levels were also found to be increased with acute stress ${ }^{(280)}$.

\section{Susceptibility to obesity}

There is a genetic background for susceptibility to obesity with interacting environmental factors; the environment alone has an impact on the inherent risk of obesity in individuals ${ }^{(5,6,281-283)}$. This has been shown in many studies in human subjects ${ }^{(2)}$.

An underlying genetic predisposition to be obesity prone or resistant is also shown in animal models ${ }^{(46,184)}$. Rats and mice known as the standard models for studying dietary obesity are different in their susceptibility to obesity: outbred Sprague-Dawley rats, Wistar rats and C57BL/6C mice can be easily categorised to prone and resistant phenotypes with ad libitum access to high-fat diets ${ }^{(7,8,21)}$. There are also strains known as genetically obese, such as Zucker falfa rats and ob/ob mice ${ }^{8,35)}$.

When exposed to high-fat diets, some animals are sensitive to high-fat diet-induced obesity and become obese (obesityprone animals), while others resist to this obesogenic effect and grow normally (resistant animals) ${ }^{(82,284)}$. Some researchers have attributed this difference to higher energy intakes in obesity-prone animals ${ }^{(51,60,97,259,285,286)}$, while others have found similar intakes in prone and resistant animals, and suggested that susceptible animals were capable of storing energy with greater efficiency ${ }^{(95,287,288)}$.

Suggested mechanisms for the difference between prone and resistant animals in responding to high-fat diets are that prone animals have lower fat oxidation ${ }^{(40,98,288,289)}$, increased lipoprotein lipase activity in their adipose tissue and no change in lipoprotein lipase activity of their muscles which favours fat storage in these animals ${ }^{(97,289,290)}$. However, Commerford et al. ${ }^{(286)}$ fed 7-week-old male Wistar rats high-fat diets ( $45 \%$ of energy) for 1 or 5 weeks and found comparable fat accumulation and lipogenesis in prone and resistant rats after provided with an isoenergetic ${ }^{14} \mathrm{C}$-labelled high-fat meal, suggesting that the increased energy intake is the main reason for accelerated weight gain in prone animals.

Dietary obese-prone animals also had increased arcuate neuropeptide Y mRNA expression (an orexigenic neuropeptide $)^{(291)}$, decreased noradrenaline turnover and $\alpha_{2^{-}}$ adrenoceptor binding in some parts of the hypothalamus (ventromedial, dorsomedial and lateral) compared with resistant animals, as well as in the pancreas and heart, which shows a reduced sympathetic activity in these organs ${ }^{(292)}$. The reduction in noradrenaline turnover in the pancreas leads to an increase in insulin release and development of obesity.

\section{Sex differences}

In humans, there are differences between the two sexes in energy expenditure and requirements as well as in fat 
metabolism and fat distribution ${ }^{(293-295)}$. Greater storage of fat in the lower body in females (gynoid) due to lower basal fat oxidation and greater number of $\alpha_{2}$-adrenoceptors, as well as decreased $\alpha_{2}$-adrenergic sensitivity in the abdominal region, all lead to more fat storage in the thigh region and less in the abdomen compared with men who have greater storage of fat in the upper body (android) ${ }^{(293-295)}$. Moreover women have more subcutaneous fat than men ${ }^{(296)}$. Despite all these differences, in a recent review of the genetic studies of obesity in different countries it was shown that overall obesity rates of males and females as determined by BMI were small and inconsistently different, with no indication of obesity in either sex being more prevalent ${ }^{(295)}$.

These differences can also been found in animal models of obesity ${ }^{(35)}$. In laboratory rats, males gain weight steadily throughout their lives while the body weight of female rats becomes stable in early adulthood ${ }^{(297)}$. As a result, female rats are better models for studying obesity during adulthood since they are more like humans in their growth patterns. Besides, more subcutaneous fat is found in females due to higher concentrations of oestrogen and progesterone receptors in these depots while males have more visceral fat related to high concentrations of androgen receptors in this $\operatorname{area}^{(298)}$

The sex of the animals may also affect the cellular response of the adipose tissue to high-fat feeding. This was shown in adult rats fed cafeteria diets for 9 weeks which led to a more rapid development of obesity in female rats, and their difference in weight compared with control animals became obvious after $5 \mathrm{~d}$ while in males this became significant after $40 \mathrm{~d}^{(44)}$. The same report showed that weight gain of male and female rats fed a supermarket diet is more similar to each other than that of rats fed chow. Therefore, the sex difference in weight gain normally seen in rats is reduced when animals are developing dietary obesity. Female golden hamsters, aged 10 weeks, fed a fatrich diet ( $52 \%$ of energy) ate significantly more energy and gained more weight than males ${ }^{(106)}$. Likewise, $10 \mathrm{~d}$ old female Wistar rats fed a cafeteria diet for 14 weeks gained more weight than their male counterparts fed the same diet, suggesting less thermogenic capacity in females when fed the cafeteria diet ${ }^{(299)}$. A study in 3-month-old SpragueDawley rats showed that female rats fed chow had higher food intake and greater increase in ghrelin and decrease in leptin levels than males following a $12 \mathrm{~h}$ fast $^{(300)}$. Moreover, an interaction between sex and site of fat accumulation was found in 6-week-old NMRI mice given different amounts of fat $(17,27,43 \cdot 5,60 \%$ of energy) for 14 weeks, with more fat accumulation in retroperitoneal and parametrial sites in females, and in subcutaneous depot in males ${ }^{(25)}$.

All together, similar to humans, male and female rats have different body fat distribution which makes them appropriate models for studying adipose tissue. Besides, female animal models are better responders to high-fat feeding, mimicking susceptibility to obesity in humans. However, in a recent review, male mice and rats are introduced as 'gold standards' for studying dietary obesity $^{(7)}$. This might be because of the oestrous cycle of the female animals which is repeated every $4-6 \mathrm{~d}$ and can affect the food intake of the animal during this period ${ }^{(301)}$.

\section{Reversibility}

Animal studies have shown that low-fat diets can induce weight loss in dietary obese rats. A reduction in energy intake and obesity reversal was found when adult male Wistar rats fed a high-fat diet at $60 \%$ of total energy for 17 weeks were switched to chow for 13 weeks ${ }^{(302)}$. Decreased energy intake and obesity reversal with significant weight and fat loss were found in weanling male $\mathrm{C} 57 \mathrm{BL} / 6$ mice switched from 17 weeks of high-fat feeding (at $58 \%$ of energy) to low-fat feeding (at $11 \%$ of energy) for 17 weeks ${ }^{(303)}$ or after 13 weeks of high-fat feeding (at $59 \%$ of energy) to low-fat feeding (10\% of energy) for 6 weeks ${ }^{(51)}$. Likewise, a reduction in energy intake and a complete reversal of diet-induced obesity were found when 13-week-old female Wistar rats originally fed high-fat diets (at 30 or $60 \%$ of energy provided by Crisco ${ }^{\circledR}$; Proctor \& Gamble, Cincinnati, OH, USA) for 8 or 14 weeks were switched to chow $^{(101)}$.

In other studies, however, ad libitum low-fat feeding was not an efficient method to completely reverse dietary obesity. For example, an initial decline in body weight followed by a plateau have been found in adult male obesity-prone and -resistant Sprague-Dawley rats after switching from 10 weeks of a high-fat diet (at $31 \%$ of energy) to chow feeding for 2 weeks ${ }^{(288)}$; however, when animals were restricted on chow to $50 \%$ of their energy intake for 3 weeks, their body weights reached the level of chow-fed control animals. Decline in body weight and a plateau were also found in adult male obesity-prone Sprague-Dawley rats switched from 10 weeks of being fed a high-fat diet (at $31 \%$ of energy) to 7 weeks of chow feeding, although their energy intake was decreased while on chow ${ }^{(82)}$. Wade ${ }^{(304)}$ reported that young male and female golden hamsters fed a high-fat diet (at $52 \%$ of energy) for 4 weeks and then switched to chow for 4 weeks (fat at $4.5 \%$ energy) decreased their energy intake and lost $80 \%$ of their weight gain from feeding on the fat-rich diet. Adult male obesity-prone Sprague-Dawley rats fed a high-fat diet (at $31 \%$ of energy) for 12 weeks and then switched to chow for 1 week decreased their energy intake (by $10-20 \%$ ) but failed to lose weight ${ }^{(305)}$.

Both hyperplasia and hypertrophy of fat cells are involved in developing obesity ${ }^{(77,78,81)}$. A total of 8 weeks of energy restriction in normal-weight adult male Sprague-Dawley rats did not result in hypoplasia despite the significant decrease in body weight and body fat ${ }^{(306)}$. When weanling male Sprague-Dawley rats made obese by feeding a diet containing chow, Crisco ${ }^{\circledR}$, sweetened condensed milk and sucrose solution for 19 weeks were then food deprived for 8 , 15 or $25 \mathrm{~d}$, body weight and fat cell size decreased, but fat cell number was comparable with that of the chow-fed control animals ${ }^{(307)}$. Another study in adult male C57BL/6J mice fed a high-fat diet (45\% of energy, Research Diets, New Brunswick, NJ, USA) for 10 weeks and then switched to chow for 2 weeks had similar results ${ }^{(308)}$. Centrally administered leptin (10 $\mu \mathrm{g}$, ICV) for $4 \mathrm{~d}$ in normal-weight adult male Sprague-Dawley rats caused a decrease in the number of inguinal fat cells ${ }^{(309)}$. Leptin injections $(5 \mu \mathrm{g}$; ICV) over $5 \mathrm{~d}$ decreased the number of fat cells in young (aged 3 months) male Sprague-Dawley rats, but not in mature (aged 8 months) animals ${ }^{(310)}$. This was also found in 
a study in mice ${ }^{(308)}$. However, a decrease in fat cell number was not found following dietary reversal of obesity in rats and mice ${ }^{(306-308)}$. These findings contrast with human studies that showed hypoplasia of adipocytes following reversal of obesity ${ }^{(78,81)}$.

\section{Conclusions}

The physiological mechanisms involved in high-fat dietinduced obesity are overconsumption of high-fat diets due to their low satiating effects, the high efficiency of dietary fat in being stored in the body as well as the alterations in the hormones involved in energy balance, such as high-fat diet-induced hyperleptinaemia and hyperinsulinaemia accompanied by leptin and insulin resistance, and lowered suppression of ghrelin secretion following high-fat diets. Among the behavioural mechanisms, the sensory facilitation of intake with high-fat diets is well understood. Meal pattern analysis of high-fat-fed animals in a pre-obese $v$. obese state could be useful to understand the development of obesity. An area for future research is to investigate whether different patterns of eating in animal models before obesity development can be a predictor of prone and resistant phenotypes, and to assess their feeding circadian rhythms. There has been extensive research on the obesogenic effects of fatty acids with different degrees of saturation but no constant pattern of outcome under different conditions has been found. More work is needed to prove that body weight can be regulated by the fatty acid profile in high-fat diets. An important key point in designing animal studies is that high-fat diets meet animals' minimal nutrient requirements, especially for protein, vitamins and minerals, to eliminate the possibility of overconsumption of the diet to fulfill these nutrient needs. The ineffectiveness of low-fat diets fed ad libitum to reverse dietary obesity induced by long-term high-fat feeding stresses the use of restricted regimens. This could help to investigate whether a significant and sustainable weight loss accompanied by decrease in fat cell number can be achieved.

\section{Acknowledgements}

The present review was supported by a grant to Professor Louise Thibault by the Natural Sciences and Engineering Research Council of Canada (NSERC RGPIN 39636-01). The authors thank Professor David A. Booth for his insightful comments and suggestions.

Both authors contributed equally to the preparation of this paper.

The authors had no conflicts of interest.

\section{References}

1. World Health Organization (2005) Obesity and overweight. http://www.who.int/mediacentre/factsheets/fs311/en/index. html

2. Ichihara S \& Yamada Y (2008) Genetic factors for human obesity. Cell Mol Life Sci 65, 1086-1098.

3. Bouchard C \& Tremblay A (1997) Genetic influences on the response of body fat and fat distribution to positive and negative energy balances in human identical twins. $J$ Nutr 127, 943S-947S.

4. Farooqi IS \& O'Rahilly S (2005) New advances in the genetics of early onset obesity. Int J Obes 29, 1149-1152.

5. De Castro JM (2004) Genes, the environment and the control of food intake. Br J Nutr 92, S59-S62.

6. Martínez-Hernandez A, Enríquez LM, Moreno-Moreno MJ, et al. (2007) Genetics of obesity. Public Health Nutr 10, $1138-1144$.

7. Reuter TY (2007) Diet-induced models for obesity and type 2 diabetes. Drug Discov Today Dis Models 4, 3-8.

8. Speakman J, Hambly C, Mitchell S, et al. (2007) Animal models of obesity. Obes Rev 8, 55-61.

9. James WPT (2008) The epidemiology of obesity: the size of the problem. J Intern Med 263, 336-352.

10. Jequier E (2002) Pathways to obesity. Int $J$ Obes 26, S12-S17.

11. Rosengren A \& Lissner L (2008) The sociology of obesity. In Obesity and Metabolism, pp. 260-270 [A Rosengren and L Lissner, editors]. Basel: Karger.

12. Hill JO, Melanson EL \& Wyatt HT (2000) Dietary fat intake and regulation of energy balance: implications for obesity. $J$ Nutr 130, 284S-288S.

13. French $\mathrm{S} \&$ Robinson T (2003) Fats and food intake. Curr Opin Clin Nutr Metab Care 6, 629-634.

14. Bray GA \& Popkin BM (1998) Dietary fat intake does affect obesity. Am J Clin Nutr 68, 1157-1173.

15. Schrauwen P \& Westerterp KR (2000) The role of high-fat diets and physical activity in the regulation of body weight. Br J Nutr 84, 417-427.

16. George V, Tremblay A, Despres JP, et al. (1990) Effect of dietary fat content on total and regional adiposity in men and women. Int J Obes 14, 1085-1094.

17. Popkin BM, Keyou G, Fengying Z, et al. (1993) The nutrition transition in China: a cross-sectional analysis. Eur J Clin Nutr 47, 333-346.

18. Saris WHM, Astrup A, Prentice AM, et al. (2000) Randomized controlled trial of changes in dietary carbohydrate/fat ratio and simple vs complex carbohydrates on body weight and blood lipids: The CARMEN study. The Carbohydrate Ratio Management in European National diets. Int J Obes 24, 1310-1318.

19. Tucker LA \& Kano MJ (1992) Dietary fat and body fat: a multivariate study of 205 adult females. Am J Clin Nutr 56, 616-622.

20. Rothwell NJ \& Stock MJ (1984) The development of obesity in animals - the role of dietary factors. Clin Endocrinol Metab 13, 437-449.

21. Buettner R, Scholmerich J \& Bollheimer LC (2007) Highfat diets: modeling the metabolic disorders of human obesity in rodents. Obesity $\mathbf{1 5}, 798-808$.

22. Warwick ZS \& Schiffman SS (1992) Role of dietary fat in calorie intake and weight gain. Neurosci Biobehav Rev 16, 585-596.

23. Boozer CN, Schoenbach G \& Atkinson RL (1995) Dietary fat and adiposity - a dose-response relationship in adult male rats fed isocalorically. Am J Physiol Endocrinol Metab 268, E546-E550.

24. Ghibaudi L, Cook J, Farley C, et al. (2002) Fat intake affects adiposity, comorbidity factors, and energy metabolism of Sprague-Dawley rats. Obes Res 10, 956-963.

25. Bourgeois F, Alexiu A \& Lemonnier D (1983) Dietaryinduced obesity: effect of dietary fats on adipose tissue cellularity in mice. Br J Nutr 49, 17-26.

26. Takahashi M, Ikemoto S \& Ezaki O (1999) Effect of the fat/carbohydrate ratio in the diet on obesity and oral glucose 
tolerance in C57BL/6J mice. J Nutr Sci Vitaminol (Tokyo) 45, 583-593.

27. Deuel HJ Jr, Movitt E, Hallman LF, et al. (1944) Studies of the comparative nutritive value of fats: I. Growth rate and efficiency of conversion of various diets to tissue. J Nutr $\mathbf{2 7}$, $107-121$.

28. Deuel HJ Jr, Meserve ER, Straub E, et al. (1947) The effect of fat level of the diet on general nutrition: I. Growth, reproduction and physical capacity of rats receiving diets containing various levels of cottonseed oil or margarine fat ad libitum. J Nutr 33, 569-582.

29. Ingle D (1949) A simple means of producing obesity in the rat. Proc Soc Exp Biol Med 72, 604-605.

30. Fenton PF \& Dowling MT (1953) Studies on obesity. 1. Nutritional obesity in mice. J Nutr 49, 319-331.

31. Sclafani A \& Springer D (1976) Dietary obesity in adult rats - similarities to hypothalamic and human obesity syndromes. Physiol Behav 17, 461-471.

32. Hebert JR, Patterson RE, Gorfine M, et al. (2003) Differences between estimated caloric requirements and self-reported caloric intake in the Women's Health Initiative. Ann Epidemiol 13, 629-637.

33. Poppitt SD, Swann D, Black AE, et al. (1998) Assessment of selective under-reporting of food intake by both obese and non-obese women in a metabolic facility. Int J Obes $\mathbf{2 2}$, $303-311$.

34. Voss S, Kroke A, Klipstein-Grobusch K, et al. (1998) Is macronutrient composition of dietary intake data affected by underreporting? Results from the EPIC-Potsdam Study. Eur J Clin Nutr 52, 119-126.

35. Thibault L, Woods SC \& Westerterp-Plantenga MS (2004) The utility of animal models of human energy homeostasis. Br J Nutr 92, S41-S45.

36. Young GS \& Kirkland JB (2007) Rat models of caloric intake and activity: relationships to animal physiology and human health. Appl Physiol Nutr Metab 32, 161-176.

37. Mickelsen O, Takahashi S \& Craig C (1955) Experimental obesity. 1 . Production of obesity in rats by feeding high-fat diets. J Nutr 57, 541-554.

38. Oscai LB (1982) Dietary-induced severe obesity - a rat model. Am J Physiol 242, R212-R215.

39. Ainslie DA, Proietto J, Fam BC, et al. (2000) Short-term, high-fat diets lower circulating leptin concentrations in rats. Am J Clin Nutr 71, 438-442.

40. Chang S, Graham B, Yakubu F, et al. (1990) Metabolic differences between obesity-prone and obesity-resistant rats. Am J Physiol 259, R1103-R1110.

41. Harrold JA, Williams G \& Widdowson PS (2000) Early leptin response to a palatable diet predicts dietary obesity in rats: key role of melanocortin-4 receptors in the ventromedial hypothalamic nucleus. J Neurochem $\mathbf{7 4}$, 1224-1228.

42. Woods SC, Seeley RJ, Rushing PA, et al. (2003) A controlled high-fat diet induces an obese syndrome in rats. J Nutr 133, 1081-1087.

43. Yaqoob P, Sherrington EJ, Jeffery NM, et al. (1995) Comparison of the effects of a range of dietary lipds upon serum and tissue lipid composition in the rat. Int J Biochem Cell Biol 27, 297-310.

44. Sclafani A \& Gorman AN (1977) Effects of age, sex, and prior body weight on the development of dietary obesity in adult rats. Physiol Behav 18, 1021-1026.

45. Schemmel R, Mickelsen O \& Tolgay Z (1969) Dietary obesity in rats: influence of diet, weight, age, and sex on body composition. Am J Physiol 216, 373-379.
46. Levin BE \& Dunn-Meynell AA (2002) Reduced central leptin sensitivity in rats with diet-induced obesity. Am J Physiol Regul Integr Comp Physiol 283, R941-R948.

47. Bell RR, Spencer MJ \& Sherriff JL (1997) Voluntary exercise and monounsaturated canola oil reduce fat gain in mice fed diets high in fat. $J$ Nutr 127, 2006-2010.

48. Cunnane SC, McAdoo KR \& Horrobin DF (1986) n-3 Essential fatty acids decrease weight gain in genetically obese mice. Br J Nutr 56, 87-95.

49. Herberg L, Doppen W, Major E, et al. (1974) Dietaryinduced hypertrophic-hyperplastic obesity in mice. J Lipid Res 15, 580-585.

50. Lemonnier D, Suquet JP, Aubert R, et al. (1975) Metabolism of mouse made obese by a high-fat diet. Diabetes Metab 1, 77-85.

51. Huang XF, Xin X, McLennan P, et al. (2004) Role of fat amount and type in ameliorating diet-induced obesity: insights at the level of hypothalamic arcuate nucleus leptin receptor, neuropeptide $\mathrm{Y}$ and pro-opiomelanocortin mRNA expression. Diabetes Obes Metab 6, 35-44.

52. Ikemoto S, Takahashi M, Tsunoda N, et al. (1996) High-fat diet-induced hyperglycemia and obesity in mice: differential effects of dietary oils. Metab Clin Exp 45, 1539-1546.

53. Ellis J, Lake A \& Hoover-Plow J (2002) Monounsaturated canola oil reduces fat deposition in growing female rats fed a high or low fat diet. Nutr Res 22, 609-621.

54. Lissner L, Heitmann BL \& Bengtsson C (2000) Population studies of diet and obesity. Br J Nutr 83, S21-S24.

55. Gray-Donald K, Jacobs-Starkey L \& Johnson-Down L (2000) Food habits of Canadians: reduction in fat intake over a generation. Can J Public Health 91, 381-385.

56. Moussavi N, Gavino V \& Receveur O (2008) Could the quality of dietary fat, and not just its quantity, be related to risk of obesity? Obesity 16, 7-15.

57. DeLany JP, Windhauser MM, Champagne CM, et al. (2000) Differential oxidation of individual dietary fatty acids in humans. Am J Clin Nutr 72, 905-911.

58. Kien CL, Bunn JY \& Ugrasbul F (2005) Increasing dietary palmitic acid decreases fat oxidation and daily energy expenditure. Am J Clin Nutr 82, 320-326.

59. Storlien LH, Huang XF, Lin S, et al. (2001) Dietary fat subtypes and obesity. World Rev Nutr Diet 88, 148-154.

60. Wang H, Storlien LH \& Huang XF (2002) Effects of dietary fat types on body fatness, leptin, and Arc leptin receptor, NPY, and AgRP mRNA expression. Am J Physiol Endocrinol Metab 282, E1352-E1359.

61. Okere IC, Chandler MP, McElfresh TA, et al. (2006) Differential effects of saturated and unsaturated fatty acid diets on cardiomyocyte apoptosis, adipose distribution, and serum leptin. Am J Physiol Heart Circ Physiol 291, $\mathrm{H} 38-\mathrm{H} 44$.

62. Cha MC \& Jones PJH (1998) Dietary fat type and energy restriction interactively influence plasma leptin concentration in rats. J Lipid Res 39, 1655-1660.

63. Hill JO, Peters JC, Lin D, et al. (1993) Lipid accumulation and body fat distribution is influenced by type of dietary fat fed to rats. Int $J$ Obes 17, 223-236.

64. Jones PJH, Toy BR \& Cha MC (1995) Differential fatty acid accretion in heart, liver and adipose tissues of rats fed beef tallow, fish-oil, olive oil and safflower oils at 3 levels of energy-intake. J Nutr 125, 1175-1182.

65. Okuno M, Kajiwara K, Imai S, et al. (1997) Perilla oil prevents the excessive growth of visceral adipose tissue in rats by down-regulating adipocyte differentiation. $J$ Nutr 127, 1752-1757.

66. Su W \& Jones PJH (1993) Dietary fatty acid composition influences energy accretion in rats. J Nutr 123, 2109-2114. 
67. Preiss-Landl K, Zimmermann R, Hämmerle G, et al. (2002) Lipoprotein lipase: the regulation of tissue specific expression and its role in lipid and energy metabolism. Curr Opin Lipidol 13, 471-481.

68. Westerterp-Plantenga MS (2004) Fat intake and energy balance effects. Physiol Behav 83, 579-585.

69. Blundell JE \& Macdiarmid JI (1997) Fat as a risk factor for overconsumption: satiation, satiety, and patterns of eating. J Am Diet Assoc 97, S63-S69.

70. Golay A \& Bobbioni E (1997) The role of dietary fat in obesity. Int J Obes 21, S2-S11.

71. Rolls BJ (2000) The role of energy density in the overconsumption of fat. J Nutr 130, 268S-271S.

72. Poppitt SD \& Prentice AM (1996) Energy density and its role in the control of food intake: evidence from metabolic and community studies. Appetite 26, 153-174.

73. Skelton JA, DeMattia L, Miller L, et al. (2006) Obesity and its therapy: from genes to community action. Pediatr Clin North Am 53, 777-794.

74. Kiess W, Petzold S, Topfer M, et al. (2008) Adipocytes and adipose tissue. Best Pract Res Clin Endocrinol Metab 22, $135-153$.

75. Kershaw EE \& Flier JS (2004) Adipose tissue as an endocrine organ. J Clin Endocrinol Metab 89, 2548-2556.

76. Sorisky A (1999) From preadipocyte to adipocyte: differentiation-directed signals of insulin from the cell surface to the nucleus. Crit Rev Clin Lab Sci 36, 1-34.

77. de Ferranti S \& Mozaffarian D (2008) The perfect storm: obesity, adipocyte dysfunction, and metabolic consequences. Clin Chem 54, 945-955.

78. Avram MM, Avram AS \& James WD (2005) Subcutaneous fat in normal and diseased states - 1. Introduction. $J$ Am Acad Dermatol 53, 663-670.

79. Hirsch J \& Han PW (1969) Cellularity of rat adipose tissue - effects of growth starvation and obesity. J Lipid Res 10, $77-82$.

80. Greenwood M \& Hirsch J (1974) Postnatal development of adipocyte cellularity in normal rat. J Lipid Res 15, 474-483.

81. Prins JB \& Orahilly S (1997) Regulation of adipose cell number in man. Clin Sci 92, 3-11.

82. Levin BE \& Dunn-Meynell AA (2002) Defense of body weight depends on dietary composition and palatability in rats with diet-induced obesity. Am J Physiol Regul Integr Comp Physiol 282, R46-R54.

83. Lee MO (1929) Determination of the surface area of the white rat with its application to the expression of metabolic results. Am J Physiol 89, 24-33.

84. Li XL, Wu GH, Xie L, et al. (2004) Experimental study on the obesity rat model induced by vitamin D. Chin J Clin Rehab 8, 1786-1787.

85. Sun Z, Zhang ZC \& Liu ZC (2002) Experimental study of diet-induced obesity animal model. Chin Pharmacol Bull 18, 466-467.

86. Kanarek RB \& Markskaufman R (1979) Developmental aspects of sucrose-induced obesity in rats. Physiol Behav 23, $881-885$.

87. Li H, Matheny M, Nicolson M, et al. (1997) Leptin gene expression increases with age independent of increasing adiposity in rats. Diabetes 46, 2035-2039.

88. Stephens DN (1980) Does the Lee obesity index measure general obesity? Physiol Behav 25, 313-315.

89. Bernardis LL (1970) Sex and age differences in hyperthermia response to ether anesthesia in weanling rats with ventromedial hypothalamic lesions. Experientia 26, $1322-1324$.

90. Bernardis LL \& Patterson BD (1968) Correlation between 'Lee index' and carcass fat content in weanling and adult female rats with hypothalamic lesions. J Endocrinol 40, 527-528.

91. Rogers P \& Webb GP (1980) Estimation of body fat in normal and obese mice. Br J Nutr 43, 83-86.

92. Lindsay RS, Hanson RL, Roumain J, et al. (2001) Body mass index as a measure of adiposity in children and adolescents: relationship to adiposity by dual energy X-ray absorptiometry and to cardiovascular risk factors. $J$ Clin Endocrinol Metab 86, 4061-4067.

93. Tzotzas T, Krassas GE \& Doumas A (2008) Body composition analysis in obesity: radionuclide and non radionuclide methods. Hell J Nucl Med 11, 63-71.

94. Holemans K, Caluwaerts S, Poston L, et al. (2004) Dietinduced obesity in the rat: a model for gestational diabetes mellitus. Am J Obstet Gynecol 190, 858-865.

95. Tulipano G, Vergoni AV, Soldi D, et al. (2004) Characterization of the resistance to the anorectic and endocrine effects of leptin in obesity-prone and obesityresistant rats fed a high-fat diet. J Endocrinol $\mathbf{1 8 3}$ 289-298.

96. Dourmashkin JT, Chang GQ, Hill JO, et al. (2006) Model for predicting and phenotyping at normal weight the longterm propensity for obesity in Sprague-Dawley rats. Physiol Behav 87, 666-678.

97. Dourmashkin JT, Chang GQ, Gayles EC, et al. (2005) Different forms of obesity as a function of diet composition. Int J Obes 29, 1368-1378.

98. Hassanain M \& Levin BE (2002) Dysregulation of hypothalamic serotonin turnover in diet-induced obese rats. Brain Res 929, 175-180.

99. Michel C, Levin BE \& Dunn-Meynell AA (2003) Stress facilitates body weight gain in genetically predisposed rats on medium-fat diet. Am J Physiol Regul Integr Comp Physiol 285, R791-R799.

100. Lissner L, Levitsky DA, Strupp BJ, et al. (1987) Dietary fat and the regulation of energy intake in human subjects. Am J Clin Nutr 46, 886-892.

101. Bartness TJ, Polk DR, McGriff WR, et al. (1992) Reversal of high-fat diet-induced obesity in female rats. Am J Physiol 263, R790-R797.

102. Jen KLC, Buison A, Pellizzon M, et al. (2003) Differential effects of fatty acids and exercise on body weight regulation and metabolism in female wistar rats. Exp Biol Med 228, 843-849.

103. Faust IM, Johnson PR, Stern JS, et al. (1978) Diet-induced adipocyte number increase in adult rats - new model of obesity. Am J Physiol 235, E279-E286.

104. Loh MY, Flatt WP, Martin RJ, et al. (1998) Dietary fat type and level influence adiposity development in obese but not lean Zucker rats. Proc Soc Exp Biol Med 218, 38-44.

105. Rolland V, Roseau S, Fromentin G, et al. (2002) Body weight, body composition, and energy metabolism in lean and obese Zucker rats fed soybean oil or butter. Am J Clin Nutr 75, 21-30.

106. Wade GN (1982) Obesity without overeating in golden hamsters. Physiol Behav 29, 701-707.

107. Pichon L, Huneau JF, Fromentin G, et al. (2006) A highprotein, high-fat, carbohydrate-free diet reduces energy intake, hepatic lipogenesis, and adiposity in rats. J Nutr 136, 1256-1260.

108. Sinitskaya N, Gourmelen S, Schuster-Klein C, et al. (2007) Increasing the fat-to-carbohydrate ratio in a high-fat diet prevents the development of obesity but not a prediabetic state in rats. Clin Sci 113, 417-425.

109. Weigle DS, Breen PA, Matthys CC, et al. (2005) A highprotein diet induces sustained reductions in appetite, ad libitum caloric intake, and body weight despite 
compensatory changes in diurnal plasma leptin and ghrelin concentrations. Am J Clin Nutr 82, 41-48.

110. Potier M, Darcel N \& Tome D (2009) Protein, amino acids and the control of food intake. Curr Opin Clin Nutr Metab Care 12, 54-58.

111. Blom WAM, Lluch A, Stafleu A, et al. (2006) Effect of a high-protein breakfast on the postprandial ghrelin response. Am J Clin Nutr 83, 211-220.

112. Saris WHM (2006) Macronutrient intake balance and the problem of obesity - old recipes and some new spices. Aktuel Ernahr Med 31, S49-S54.

113. Morrison CD, Xi X, White CL, et al. (2007) Amino acids inhibit Agrp gene expression via an mTOR-dependent mechanism. Am J Physiol Endocrinol Metab 293, E165-E171.

114. Huang XF, Liu YX, Rahardjo GL, et al. (2008) Effects of diets high in whey, soy, red meat and milk protein on body weight maintenance in diet-induced obesity in mice. Nutr Diet 65, S53-S59.

115. Ailhaud G, Massiera F, Weill P, et al. (2006) Temporal changes in dietary fats: role of $n-6$ polyunsaturated fatty acids in excessive adipose tissue development and relationship to obesity. Prog Lipid Res 45, 203-236.

116. Clarke SD (2000) Polyunsaturated fatty acid regulation of gene transcription: a mechanism to improve energy balance and insulin resistance. Br J Nutr 83, S59-S66.

117. Lawton GL, Delargy HJ, Brockman J, et al. (2000) The degree of saturation of fatty acids influences post-ingestive satiety. Br J Nutr 83, 473-482.

118. Lichtenbelt WDV, Mensink RP \& Westerterp KR (1997) The effect of fat composition of the diet on energy metabolism. Z Ernahrungswiss 36, 303-305.

119. Piers LS, Walker KZ, Stoney RM, et al. (2003) Substitution of saturated with monounsaturated fat in a 4-week diet affects body weight and composition of overweight and obese men. Br J Nutr 90, 717-727.

120. Shillabeer G \& Lau DCW (1994) Regulation of new fat-cell formation in rats - the role of dietary fats. J Lipid Res $\mathbf{3 5}$, 592-600.

121. Silva APS, Guimaraes DED, Mizurini DM, et al. (2006) Dietary fatty acids early in life affect lipid metabolism and adiposity in young rats. Lipids 41, 535-541.

122. Takeuchi H, Matsuo T, Tokuyama K, et al. (1995) Dietinduced thermogenesis is lower in rats fed a lard diet than in those fed a high-oleic acid safflower oil diet, a safflower oil diet or a linseed oil diet. J Nutr 125, 920-925.

123. Casas-Agustench P, Lopez-Uriarte P, Bullo M, et al. (2009) Acute effects of three high-fat meals with different fat saturations on energy expenditure, substrate oxidation and satiety. Clin Nutr 28, 39-45.

124. Piers LS, Walker KZ, Stoney RM, et al. (2002) The influence of the type of dietary fat on postprandial fat oxidation rates: monounsaturated (olive oil) vs saturated fat (cream). Int J Obes 26, 814-821.

125. Soares MJ, Cummings SJ, Mamo JCL, et al. (2004) The acute effects of olive oil $v$. cream on postprandial thermogenesis and substrate oxidation in postmenopausal women. Br J Nutr 91, 245-252.

126. Beardshall K, Morarji Y, Bloom SR, et al. (1989) Saturation of fat and cholecystokinin release: implications for pancreatic carcinogenesis. Lancet ii, 1008-1010.

127. Alfenas RCG \& Mattes RD (2003) Effect of fat sources on satiety. Obes Res 11, 183-187.

128. George J, Mulkins M, Casey S, et al. (2000) The effects of $n-6$ polyunsaturated fatty acid supplementation on the lipid composition and atherogenesis in mouse models of atherosclerosis. Atherosclerosis 150, 285-293.
129. Nagao K \& Yanagita T (2008) Bioactive lipids in metabolic syndrome. Prog Lipid Res 47, 127-146.

130. Takeuchi H, Sekine S, Kojima K, et al. (2008) The application of medium-chain fatty acids: edible oil with a suppressing effect on body fat accumulation. Asia Pac $J$ Clin Nutr 17, 320-323.

131. Simón E, Fernández-Quintela A, Del Puy Portillo M, et al. (2000) Effects of medium-chain fatty acids on body composition and protein metabolism in overweight rats. J Physiol Biochem 56, 337-346.

132. Takeuchi H, Noguchi O, Sekine S, et al. (2006) Lower weight gain and higher expression and blood levels of adiponectin in rats fed medium-chain TAG compared with long-chain TAG. Lipids 41, 207-212.

133. Bray GA, Lee M \& Bray TL (1980) Weight gain of rats fed medium-chain triglycerides is less than rats fed long-chain triglycerides. Int J Obes 4, 27-32.

134. Hwang SG, Yano H \& Kawashima R (1992) The influence of dietary medium and long chain triglycerides on growth performances and fat deposition in growing rats. J Nutr Sci Vitaminol 38, 127-139.

135. Noguchi O, Takeuchi H, Kubota F, et al. (2002) Larger diet-induced thermogenesis and less body fat accumulation in rats fed medium-chain triacylglycerols than in those fed long-chain triacylglycerols. J Nutr Sci Vitaminol 48, 524-529.

136. Stubbs RJ \& Harbron CG (1996) Covert manipulation of the ratio of medium- to long-chain triglycerides in isoenergetically dense diets: effect on food intake in ad libitum feeding men. Int J Obes 20, 435-444.

137. Tsuji H, Kasai M, Takeuchi H, et al. (2001) Dietary medium-chain triacylglycerols suppress accumulation of body fat in a double-blind, controlled trial in healthy men and women. J Nutr 131, 2853-2859.

138. Garaulet M, Perez-Llamas F, Perez-Ayala M, et al. (2001) Site-specific differences in the fatty acid composition of abdominal adipose tissue in an obese population from a Mediterranean area: relation with dietary fatty acids, plasma lipid profile, serum insulin, and central obesity. Am J Clin Nutr 74, 585-591.

139. Nogi A, Yang JJ, Li LM, et al. (2007) Plasma n-3 polyunsaturated fatty acid and cardiovascular disease risk factors in Japanese, Korean and Mongolian workers. J Occup Health 49, 205-216.

140. Simopoulos AP (2004) Omega-6/omega-3 essential fatty acid ratio and chronic diseases. Food Rev Int 20, 77-90.

141. Kennedy A, Martinez K, Schmidt S, et al. (2010) Antiobesity mechanisms of action of conjugated linoleic acid. J Nutr Biochem 21, 171-179.

142. Park Y (2009) Conjugated linoleic acid (CLA): good or bad trans fat? J Food Comp Anal 22, Suppl. 1, S4-S12.

143. Moon HS, Lee HG, Seo JH, et al. (2009) Antiobesity effect of ??pegylated conjugated linoleic acid on high-fat dietinduced obese C57BL/6J $(o b / o b)$ mice: attenuation of insulin resistance and enhancement of antioxidant defenses. J Nutr Biochem 20, 187-194.

144. Parra P, Palou A \& Serra F (2010) Moderate doses of conjugated linoleic acid reduce fat gain, maintain insulin sensitivity without impairing inflammatory adipose tissue status in mice fed a high fat diet. Nutr Metab 7, 5.

145. Norris LE, Collene AL, Asp ML, et al. (2009) Comparison of dietary conjugated linoleic acid with safflower oil on body composition in obese postmenopausal women with type 2 diabetes mellitus. Am J Clin Nutr 90, 468-476.

146. Sahin H, Uyanik F \& Inanc N (2008) Effects of conjugated linoleic acid on body composition and selected biochemical parameters in obese women. Pak J Nutr 7, 546-549. 
147. Halade GV, Rahman MM \& Fernandes G (2010) Differential effects of conjugated linoleic acid isomers in insulin-resistant female C57BL/6J mice. J Nutr Biochem 21, 332-337.

148. Ingelsson E \& Risérus U (2008) Effects of trans10cis 12CLA-induced insulin resistance on retinol-binding protein 4 concentrations in abdominally obese men. Diabetes Res Clin Pract 82, e23-e24.

149. Van Nieuwenhuyzen W \& Adelmann R (2007) Multipurpose functions of MCT oils - medium chain triglycerides have unique functions. Agro Food Ind Hi-Tech 18, 34-36.

150. Prpic V, Watson PM, Frampton IC, et al. (2002) Adaptive changes in adipocyte gene expression differ in AKR/J and SWR/J mice during diet-induced obesity. J Nutr 132, 3325-3332.

151. Roberts CK, Berger JJ \& Barnard RJ (2002) Long-term effects of diet on leptin, energy intake, and activity in a model of diet-induced obesity. J Appl Physiol 93, 887-893.

152. Drewnowski A (2003) The role of energy density. Lipids 38, 109-115.

153. Rolls BJ, Bell EA, Castellanos VH, et al. (1999) Energy density but not fat content of foods affected energy in lean and obese women. Am J Clin Nutr 69, 863-871.

154. Westerterp-Plantenga MS (2004) Effects of energy density of daily food intake on long-term energy intake. Physiol Behav 81, 765-771.

155. Rolls BJ \& Bell EA (1999) Intake of fat and carbohydrate: role of energy density. Eur J Clin Nutr 53, S166-S173.

156. Stubbs RJ \& Whybrow S (2004) Energy density, diet composition and palatability: influences on overall food energy intake in humans. Physiol Behav 81, 755-764.

157. Institute for Laboratory Animal Research (1995) The Nutritional Requirements of Rats, 4th revised ed. Washington, DC: National Academies Press.

158. Blundell JE, Lawton CL, Cotton JR, et al. (1996) Control of human appetite: implications for the intake of dietary fat. Annu Rev Nutr 16, 285-319.

159. Lucas F, Ackroff K \& Sclafani A (1998) High-fat diet preference and overeating mediated by postingestive factors in rats. Am J Physiol Regul Integr Comp Physiol 275, $\mathrm{R} 1511-\mathrm{R} 1522$

160. Warwick ZS \& Weingarten HP (1995) Determinants of high-fat diet hyperphagia - experimental dissection of orosensory and postingestive effects. Am J Physiol Regul Integr Comp Physiol 269, R30-R37.

161. Covasa M \& Ritter RC (2000) Adaptation to high-fat diet reduces inhibition of gastric emptying by CCK and intestinal oleate. Am J Physiol Regul Integr Comp Physiol 278, R166-R170.

162. Little TJ, Horowitz M \& Feinle-Bisset C (2007) Modulation by high-fat diets of gastrointestinal function and hormones associated with the regulation of energy intake: implications for the pathophysiology of obesity. Am J Clin Nutr 86, 531-541.

163. Scharrer E (1999) Control of food intake by fatty acid oxidation and ketogenesis. Nutrition 15, 704-714.

164. Kahler A, Zimmermann M \& Langhans W (1999) Suppression of hepatic fatty acid oxidation and food intake in men. Nutrition 15, 819-828.

165. Tso P \& Liu M (2004) Apolipoprotein A-IV, food intake, and obesity. Physiol Behav 83, 631-643.

166. Woods SC, D'Alessio DA, Tso P, et al. (2004) Consumption of a high-fat diet alters the homeostatic regulation of energy balance. Physiol Behav 83, 573-578.

167. Coll AP, Farooqi IS \& O'Rahilly S (2007) The hormonal control of food intake. Cell 129, 251-262.
168. Crowell MD, Decker GA, Levy R, et al. (2006) Gut-brain neuropeptides in the regulation of ingestive behaviors and obesity. Am J Gastroenterol 101, 2848-2856.

169. Gale SM, Castracane VD \& Mantzoros CS (2004) Energy homeostasis, obesity and eating disorders: recent advances in endocrinology. J Nutr 134, 295-298.

170. Zhang YY, Proenca R, Maffei M, et al. (1994) Positional cloning of the mouse obese gene and its human homolog. Nature 372, 425-432.

171. Lin S, Storlien LH \& Huang XF (2000) Leptin receptor, NPY, POMC mRNA expression in the diet-induced obese mouse brain. Brain Res 875, 89-95.

172. MacDougald OA, Hwang CS, Fan H, et al. (1995) Regulated expression of the obese gene product (leptin) in white adipose tissue and 3T3-L1 adipocytes. Proc Natl Acad Sci U S A 92, 9034-9037.

173. Pelleymounter MA, Cullen MJ, Baker MB, et al. (1995) Effects of the obese gene-product on body-weight regulation in ob/ob mice. Science 269, 540-543.

174. Halaas JL, Gajiwala KS, Maffei M, et al. (1995) Weightreducing effects of the plasma protein encoded by the obese gene. Science 269, 543-546.

175. Randeva HS, Karteris E, Lewandowski KC, et al. (2003) Circadian rhythmicity of salivary leptin in healthy subjects. Mol Genet Metab 78, 229-235.

176. Saad MF, Riad-Gabriel MG, Khan A, et al. (1998) Diurnal and ultradian rhythmicity of plasma leptin: effects of gender and adiposity. J Clin Endocrinol Metab 83, 453-459.

177. Poppitt SD, Leahy E, Keogh GF, et al. (2006) Effect of high-fat meals and fatty acid saturation on postprandial levels of the hormones ghrelin and leptin in healthy men. Eur J Clin Nutr 60, 77-84.

178. Bodosi B, Gardi J, Hajdu I, et al. (2004) Rhythms of ghrelin, leptin, and sleep in rats: effects of the normal diurnal cycle, restricted feeding, and sleep deprivation. Am J Physiol Regulat Integr Comp Physiol 287, R1071-R1079.

179. Chacon F, Esquifino AI, Perello M, et al. (2005) 24-Hour changes in $\mathrm{ACTH}$, corticosterone, growth hormone, and leptin levels in young male rats subjected to calorie restriction. Chronobiol Int 22, 253-265.

180. Frederich RC, Hamann A, Anderson S, et al. (1995) Leptin levels reflect body lipid content in mice: evidence for dietinduced resistance to leptin action. Nat Med 1, 1311-1314.

181. Leibowitz SF, Chang GQ, Dourmashkin JT, et al. (2006) Leptin secretion after a high-fat meal in normal-weight rats: strong predictor of long-term body fat accrual on a high-fat diet. Am J Physiol Endocrinol Metab 290, E258-E267.

182. Lin L, Martin R, Schaffhauser AO, et al. (2001) Acute changes in the response to peripheral leptin with alteration in the diet composition. Am J Physiol Regul Integr Comp Physiol 280, R504-R509.

183. Surwit RS \& Collins S (2001) Revisiting lessons from the C57BL/6J mouse. Am J Physiol Endocrinol Metab 280, E825-E826.

184. Levin BE, Dunn-Meynell AA, Ricci MR, et al. (2003) Abnormalities of leptin and ghrelin regulation in obesityprone juvenile rats. Am J Physiol Endocrinol Metab 285, E949-E957.

185. Fam BC, Morris MJ, Hansen MJ, et al. (2007) Modulation of central leptin sensitivity and energy balance in a rat model of diet-induced obesity. Diabetes Obes Metab 9 , $840-852$.

186. Lin S, Thomas TC, Storlien LH, et al. (2000) Development of high fat diet-induced obesity and leptin resistance in C57B1/6J mice. Int J Obes 24, 639-646.

187. Hynes GR, Heshka J, Chadee K, et al. (2003) Effects of dietary fat type and energy restriction on adipose tissue fatty 
acid composition and leptin production in rats. $J$ Lipid Res 44, 893-901.

188. Jang IS, Hwang DY, Chae KR, et al. (2003) Role of dietary fat type in the development of adiposity from dietary obesity-susceptible Sprague-Dawley rats. Br J Nutr 89, 429-437.

189. Kojima M, Hosoda H, Date Y, et al. (1999) Ghrelin is a growth-hormone-releasing acylated peptide from stomach. Nature 402, 656-660.

190. Cummings DE, Purnell JQ, Frayo RS, et al. (2001) A preprandial rise in plasma ghrelin levels suggests a role in meal initiation in humans. Diabetes 50, 1714-1719.

191. Tschop M, Smiley DL \& Heiman ML (2000) Ghrelin induces adiposity in rodents. Nature 407, 908-913.

192. Natalucci G, Riedl S, Gleiss A, et al. (2005) Spontaneous 24-h ghrelin secretion pattern in fasting subjects: maintenance of a meal-related pattern. Eur J Endocrinol 152, $845-850$.

193. English PJ, Ghatei MA, Malik IA, et al. (2002) Food fails to suppress ghrelin levels in obese humans. J Clin Endocrinol Metab 87, 2984-2987.

194. Marzullo P, Verti B, Savia G, et al. (2004) The relationship between active ghrelin levels and human obesity involves alterations in resting energy expenditure. J Clin Endocrinol Metab 89, 936-939.

195. Reinehr T, Roth CL, Alexy U, et al. (2005) Ghrelin levels before and after reduction of overweight due to a low-fat high-carbohydrate diet in obese children and adolescents. Int J Obes 29, 362-368.

196. le Roux CW, Patterson M, Vincent RP, et al. (2005) Postprandial plasma ghrelin is suppressed proportional to meal calorie content in normal-weight but not obese subjects. J Clin Endocrinol Metab 90, 1068-1071.

197. Tentolouris N, Kokkinos A, Tsigos C, et al. (2004) Differential effects of high-fat and high-carbohydrate content isoenergetic meals on plasma active ghrelin concentrations in lean and obese women. Horm Metab Res 36, 559-563.

198. Lithander FE, Keogh GF, Wang Y, et al. (2008) No evidence of an effect of alterations in dietary fatty acids on fasting adiponectin over 3 weeks. Obesity 16, 592-599.

199. Sanchez J, Oliver P, Pico C, et al. (2004) Diurnal rhythms of leptin and ghrelin in the systemic circulation and in the gastric mucosa are related to food intake in rats. Pflugers Arch 448, 500-506.

200. Moesgaard SG, Ahren B, Carr RD, et al. (2004) Effects of high-fat feeding and fasting on ghrelin expression in the mouse stomach. Regul Pept 120, 261-267.

201. Perreault M, Istrate N, Wang L, et al. (2004) Resistance to the orexigenic effect of ghrelin in dietary-induced obesity in mice: reversal upon weight loss. Int J Obes 28, 879-885.

202. Liu X, York DA \& Bray GA (2004) Regulation of ghrelin gene expression in stomach and feeding response to a ghrelin analogue in two strains of rats. Peptides 25, 2171-2177.

203. Beck B, Musse N \& Stricker-Krongrad A (2002) Ghrelin, macronutrient intake and dietary preferences in LongEvans rats. Biochem Biophys Res Commun 292, 1031-1035.

204. Greeley GH, Reed JT, Qi X, et al. (2007) Increased adiposity during high fat diet does not participate in suppression of stomach ghrelin production and secretion. Gastroenterology 132, A586.

205. Overduin J, Frayo RS, Grill HJ, et al. (2005) Role of the duodenum and macronutrient type in ghrelin regulation. Endocrinology 146, 845-850.

206. Sánchez J, Cladera MM, Llopis M, et al. (2010) The different satiating capacity of $\mathrm{CHO}$ and fats can be mediated by different effects on leptin and ghrelin systems. Behav Brain Res 124, 183-188.

207. Lichtenstein AH \& Schwab US (2000) Relationship of dietary fat to glucose metabolism. Atherosclerosis 150, 227-243.

208. Riccardi G, Giacco R \& Rivellese AA (2004) Dietary fat, insulin sensitivity and the metabolic syndrome. Clin Nutr 23, 447-456.

209. Bray GA, Lovejoy JC, Smith SR, et al. (2002) The influence of different fats and fatty acids on obesity, insulin resistance and inflammation. J Nutr 132, 2488-2491.

210. Lovejoy JC, Champagne CM, Smith SR, et al. (2001) Relationship of dietary fat and serum cholesterol ester and phospholipid fatty acids to markers of insulin resistance in men and women with a range of glucose tolerance. Metab Clin Exp 50, 86-92.

211. Vessby B, Uusitupa M, Hermansen K, et al. (2001) Substituting dietary saturated for monounsaturated fat impairs insulin sensitivity in healthy men and women: The KANWU study. Diabetologia 44, 312-319.

212. Barnard RJ, Roberts CK, Varon SM, et al. (1998) Dietinduced insulin resistance precedes other aspects of the metabolic syndrome. J Appl Physiol 84, 1311-1315.

213. Storlien LH, Higgins JA, Thomas TC, et al. (2000) Diet composition and insulin action in animal models. Br J Nutr 83, S85-S90.

214. Tsitouras PD, Gucciardo F, Salbe AD, et al. (2008) High omega-3 fat intake improves insulin sensitivity and reduces CRP and IL6, but does not affect other endocrine axes in healthy older adults. Horm Metab Res 40, 199-205.

215. Lombardo YB, Hein G \& Chicco A (2007) Metabolic syndrome: effects of $n$-3 PUFAs on a model of dyslipidemia, insulin resistance and adiposity. Lipids 42, 427-437.

216. Toschke AM, Kuchenhoff H, Koletzko B, et al. (2005) Meal frequency and childhood obesity. Obes Res 13, 1932-1938.

217. Ma YS, Bertone ER, Stanek EJ, et al. (2003) Association between eating patterns and obesity in a free-living US adult population. Am J Epidemiol 158, 85-92.

218. De Castro JM (1995) Social facilitation of food intake in humans. Appetite 24, 260.

219. Herman CP, Roth DA \& Polivy J (2003) Effects of the presence of others on food intake: a normative interpretation. Psychol Bull 129, 873-886.

220. Redd M \& De Castro JM (1992) Social facilitation of eating: effects of social instruction on food intake. Physiol Behav 52, 749-754.

221. Brown KJ \& Grunberg NE (1996) Effects of environmental conditions on food consumption in female and male rats. Physiol Behav 60, 293-297.

222. Feunekes GIJ, De Graaf C \& Van Staveren WA (1995) Social facilitation of food intake is mediated by meal duration. Physiol Behav 58, 551-558.

223. Lopak V \& Eikelboom R (2000) Pair housing induced feeding suppression: individual housing not novelty. Physiol Behav 71, 329-333.

224. Lopak V \& Eikelboom R (2004) Modulation of the pair housing induced feeding suppression. Physiol Behav 83, $157-164$

225. O'Connor R \& Eikelboom R (2000) The effects of changes in housing on feeding and wheel running. Physiol Behav 68, 361-371.

226. Perez C, Canal JR, Dominguez E, et al. (1997) Individual housing influences certain biochemical parameters in the rat. Lab Anim 31, 357-361.

227. Scalera G (1992) Taste preferences, body weight gain, food and fluid intake in singly or group-housed rats. Physiol Behav 52, 935-943. 
228. Sclafani A \& Springer D (1976) Dietary obesity in adult rats - similarities to hypothalamic and human obesity syndromes. Physiol Behav 17, 461-471.

229. Dallman MF, La Fleur SE, Pecoraro NC, et al. (2004) Minireview: glucocorticoids - food intake, abdominal obesity, and wealthy nations in 2004. Endocrinology 145, 2633-2638.

230. Dallman MF, Pecoraro N, Akana SF, et al. (2003) Chronic stress and obesity: a new view of 'comfort food'. Proc Natl Acad Sci U S A 100, 11696-11701.

231. Torres SJ \& Nowson CA (2007) Relationship between stress, eating behavior, and obesity. Nutrition 23, 887-894.

232. Yeomans MR, Blundell JE \& Leshem M (2004) Palatability: response to nutritional need or need-free stimulation of appetite? Br J Nutr 92, S3-S14.

233. Yamaguchi S \& Ninomiya K (2000) Umami and food palatability. J Nutr 130, 921S-926S.

234. Swinburn BA \& Ravussin E (1994) Energy and macronutrient metabolism. Baillieres Clin Endocrinol Metab 8, $527-548$

235. LeBlanc J \& Labrie A (1997) A possible role for palatability of the food in diet-induced thermogenesis. Int J Obes 21, $1100-1103$.

236. Holt SHA, Delargy HJ, Lawton CL, et al. (1999) The effects of high-carbohydrate vs high-fat breakfasts on feelings of fullness and alertness, and subsequent food intake. Int $J$ Food Sci Nutr 50, 13-28.

237. Sclafani A (2001) Post-ingestive positive controls of ingestive behavior. Appetite 36, 79-83.

238. Warwick ZS, Schiffman SS \& Anderson JJB (1990) Relationship of dietary fat content to food preferences in young rats. Physiol Behav 48, 581-586.

239. Fushiki $\mathrm{T} \&$ Kawai $\mathrm{T}$ (2005) Chemical reception of fats in the oral cavity and the mechanism of addiction to dietary fat. Chem Senses 30, i184-i185.

240. Mizushige T, Inoue K \& Fushiki T (2007) Why is fat so tasty? Chemical reception of fatty acid on the tongue. J Nutr Sci Vitaminol 53, 1-4.

241. Gilbertson TA, Fontenot DT, Liu LD, et al. (1997) Fatty acid modulation of $\mathrm{K}^{+}$channels in taste receptor cells: gustatory cues for dietary fat. Am J Physiol Cell Physiol 272, C1203-C1210.

242. Mattes RD (2005) Fat taste and lipid metabolism in humans. Physiol Behav 86, 691-697.

243. Fabry P, Hejda S, Cerny K, et al. (1966) Effect of meal frequency in schoolchildren. Changes in weight-height proportion and skinfold thickness. Am J Clin Nutr 18, 358-361.

244. Bertéus Forslund H, Lindroos AK, Sjöström L, et al. (2002) Meal patterns and obesity in Swedish women - a simple instrument describing usual meal types, frequency and temporal distribution. Eur J Clin Nutr 56, 740-747.

245. Andersson I \& Rössner S (1996) Meal patterns in obese and normal weight men: the 'Gustaf' study. Eur J Clin Nutr 50, 639-646.

246. Qin LQ, Li J, Wang Y, et al. (2003) The effects of nocturnal life on endocrine circadian patterns in healthy adults. Life Sci 73, 2467-2475.

247. Kant AK, Schatzkin A \& Ballard-Barbash R (1997) Evening eating and subsequent long-term weight change in a national cohort. Int J Obes 21, 407-412.

248. Taylor E, Missik E, Hurley R, et al. (2004) Obesity treatment: broadening our perspective. Am J Health Behav 28, 242-249.

249. Bellisle F (2004) Impact of the daily meal pattern on energy balance. Scand J Nutr Naringsforsk 48, 114-118.
250. LeMagnen J \& Devos M (1970) Metabolic correlates of meal onset in free food intake of rats. Physiol Behav 5, 805-814.

251. Clifton PG (2000) Meal patterning in rodents: psychopharmacological and neuroanatomical studies. Neurosci Biobehav Rev 24, 213-222.

252. Prins AA, Dejongnagelsmit A, Keijser J, et al. (1986) Daily rhythms of feeding in the genetically-obese and lean Zucker rats. Physiol Behav 38, 423-426.

253. LeMagnen J (1988) Lipogenesis, lipolysis and feeding rhythms. Ann Endocrinol (Paris) 49, 98-104.

254. Becker EE \& Grinker JA (1977) Meal patterns in genetically obese Zucker rat. Physiol Behav 18, 685-692.

255. Fukagawa K, Sakata T, Yoshimatsu H, et al. (1992) Advance shift of feeding circadian-rhythm induced by obesity progression in Zucker rats. Am J Physiol 263, R1169-R1175.

256. Ho A \& Chin A (1988) Circadian feeding and drinking patterns of genetically-obese mice fed solid chow diet. Physiol Behav 43, 651-656.

257. Strohmayer AJ \& Smith GP (1987) The meal pattern of genetically-obese (ob ob) mice. Appetite 8, 111-123.

258. Drewnowski A, Cohen AE, Faust IM, et al. (1984) Mealtaking behavior is related to predisposition to dietary obesity in the rat. Physiol Behav 32, 61-67.

259. Farley C, Cook JA, Spar BD, et al. (2003) Meal pattern analysis of diet-induced obesity in susceptible and resistant rats. Obes Res 11, 845-851.

260. Cottone P, Sabino V, Nagy TR, et al. (2007) Feeding microstructure in diet-induced obesity susceptible versus resistant rats: central effects of urocortin 2. J Physiol (London) 583, 487-504.

261. Paulino G, Darcel N, Tome D, et al. (2008) Adaptation of lipid-induced satiation is not dependent on caloric density in rats. Physiol Behav 93, 930-936.

262. Synowski SJ, Smart AB \& Warwick ZS (2005) Meal size of high-fat food is reliably greater than high-carbohydrate food across externally-evoked single-meal tests and long-term spontaneous feeding in rat. Appetite 45, 191-194.

263. Mistlberger RE, Lukman H \& Nadeau BG (1998) Circadian rhythms in the Zucker obese rat: assessment and intervention. Appetite 30, 255-267.

264. Thibault L \& Booth DA (1999) Macronutrient-specific dietary selection in rodents and its neural bases. Neurosci Biobehav Rev 23, 457-528.

265. Branth S, Ronquist G, Stridsberg M, et al. (2007) Development of abdominal fat and incipient metabolic syndrome in young healthy men exposed to long-term stress. Nutr Metab Cardiovasc Dis 17, 427-435.

266. Laitinen J, Ek E \& Sovio U (2002) Stress-related eating and drinking behavior and body mass index and predictors of this behavior. Prev Med 34, 29-39.

267. Rivenes AC, Harvey SB \& Mykletun A (2009) The relationship between abdominal fat, obesity, and common mental disorders: results from the HUNT Study. $J$ Psychosom Res 66, 269-275.

268. Zhao G, Ford ES, Dhingra S, et al. (2009) Depression and anxiety among US adults: associations with body mass index. Int $J$ Obes 33, 257-266.

269. Allison DB, Newcomer JW, Dunn AL, et al. (2009) Obesity among those with mental disorders. A National Institute of Mental Health meeting report. Am J Prev Med 36, 341-350.

270. Pecoraro N, Reyes F, Gomez F, et al. (2004) Chronic stress promotes palatable feeding, which reduces signs of stress: feedforward and feedback effects of chronic stress. Endocrinology 145, 3754-3762.

271. Oliver G \& Wardle J (1999) Perceived effects of stress on food choice. Physiol Behav 66, 511-515. 
272. Levin BE, Richard D, Michel C, et al. (2000) Differential stress responsivity in diet-induced obese and resistant rats. Am J Physiol Regul Integr Comp Physiol 279, R1357-R1364.

273. Marti O, Marti J \& Armario A (1994) Effects of chronic stress on food intake in rats: influence of stressor intensity and duration of daily exposure. Physiol Behav 55, 747-753.

274. Rowland NE \& Antelman SM (1976) Stress-induced hyperphagia and obesity in rats: a possible model for understanding human obesity. Science 191, 310-312.

275. Legendre A \& Harris RBS (2006) Exaggerated response to mild stress in rats fed high-fat diet. Am J Physiol Regul Integr Comp Physiol 291, R1288-R1294.

276. Tamashiro KLK, Hegeman MA \& Sakai RR (2006) Chronic social stress in a changing dietary environment. Physiol Behav 89, 536-542.

277. Teegarden SL \& Bale TL (2008) Effects of stress on dietary preference and intake are dependent on access and stress sensitivity. Physiol Behav 93, 713-723.

278. Adam TC \& Epel ES (2007) Stress, eating and the reward system. Physiol Behav 91, 449-458.

279. Ochi M, Tominaga K, Tanaka F, et al. (2008) Effect of chronic stress on gastric emptying and plasma ghrelin levels in rats. Life Sci 82, 862-868.

280. Kristenssson E, Sundqvist M, Astin M, et al. (2006) Acute psychological stress raises plasma ghrelin in the rat. Regul Pept 134, 114-117.

281. Karnehed N, Tynelius P, Heitmann BL, et al. (2006) Physical activity, diet and gene-environment interactions in relation to body mass index and waist circumference: the Swedish Young Male Twins Study. Public Health Nutr 9, 851-858.

282. Marrades MP, Martinez JA \& Moreno-Aliaga MJ (2007) Differences in short-term metabolic responses to a lipid load in lean (resistant) vs obese (susceptible) young male subjects with habitual high-fat consumption. Eur J Clin Nutr 61, 166-174.

283. Speechly DP \& Buffenstein R (2000) Appetite dysfunction in obese males: evidence for role of hyperinsulinaemia in passive overconsumption with a high fat diet. Eur J Clin Nutr 54, 225-233.

284. Levin BE, Dunn-Meynell AA, McMinn JE, et al. (2003) A new obesity-prone, glucose-intolerant rat strain (f.Dio). Am J Physiol Regul Integr Comp Physiol 285, R1184-R1191.

285. Commerford SR, Pagliassotti MJ, Melby CL, et al. (2000) Fat oxidation, lipolysis, and free fatty acid cycling in obesity-prone and obesity-resistant rats. Am J Physiol Endocrinol Metab 279, E875-E885.

286. Commerford SR, Pagliassotti MJ, Melby CL, et al. (2001) Inherent capacity for lipogenesis or dietary fat retention is not increased in obesity-prone rats. Am J Physiol Regul Integr Comp Physiol 280, R1680-R1687.

287. Abdoulaye D, Wetzler S, Goubern M, et al. (2006) Comparison of energy balance in two inbred strains of rats: Fischer F344 prone to obesity and Lou rats resistant to obesity. Physiol Behav 87, 245-250.

288. Levin BE \& Dunn-Meynell AA (2000) Defense of body weight against chronic caloric restriction in obesity-prone and -resistant rats. Am J Physiol Regul Integr Comp Physiol 278, R231-R237.

289. Jackman MR, Kramer RE, MacLean PS, et al. (2006) Trafficking of dietary fat in obesity-prone and obesityresistant rats. Am J Physiol-Endocrinol Metab 291, E1083-E1091.

290. Pagliassotti MJ, Knobel SM, Shahrokhi KA, et al. (1994) Time-course of adaptation to a high-fat diet in obesity-resistant and obesity-prone rats. Am J Physiol 267, R659-R664.

291. Levin BE \& Dunn-Meynell AA (1997) Dysregulation of arcuate nucleus preproneuropeptide $\mathrm{Y}$ mRNA in dietinduced obese rats. Am J Physiol Regul Integr Comp Physiol 272, R1365-R1370.

292. Levin BE (1995) Reduced norepinephrine turnover in organs and brains of obesity-prone rats. Am J Physiol Regul Integr Comp Physiol 268, R389-R394.

293. Blaak E (2001) Gender differences in fat metabolism. Curr Opin Clin Nutr Metab Care 4, 499-502.

294. Power ML \& Schulkin J (2008) Sex differences in fat storage, fat metabolism, and the health risks from obesity: possible evolutionary origins. Br J Nutr 99, 931-940.

295. Sweeting HN (2008) Gendered dimensions of obesity in childhood and adolescence. Nutr $J$ (epublication 14 January 2008).

296. Geary N (2004) Is the control of fat ingestion sexually differentiated? Physiol Behav 83, 659-671.

297. Charles River Laboratories (2006) Research models and services. http://www.criver.com/flex_content_area/ documents/rm_rm_c_sprague_dawley_rats.pdf (accessed February 2009)

298. Mayes JS \& Watson GH (2004) Direct effect of sex steroid hormones on adipose tissues and obesity. Obes Rev 5, 197-216.

299. Rodríguez AM, Quevedo-Coli S, Roca P, et al. (2001) Sex-dependent dietary obesity, induction of UCPs, and leptin expression in rat adipose tissues. Obes Res 9, 579-588.

300. Gayle DA, Desai M, Casillas E, et al. (2006) Genderspecific orexigenic and anorexigenic mechanisms in rats. Life Sci 79, 1531-1536.

301. Andersen ME, Clewell HJ, Gearhart J, et al. (1997) Pharmacodynamic model of the rat estrus cycle in relation to endocrine disruptors. J Toxicol Environ Health 52, 189-209.

302. Hill JO, Dorton J, Sykes MN, et al. (1989) Reversal of dietary obesity is influenced by its duration and severity. Int J Obes 13, 711-722.

303. Parekh PI, Petro AE, Tiller JM, et al. (1998) Reversal of diet-induced obesity and diabetes in C57BL/6J mice. Metab Clin Exp 47, 1089-1096.

304. Wade GN (1983) Dietary obesity in golden hamsters: reversibility and effects of sex and photoperiod. Physiol Behav 30, 131-137.

305. Levin BE \& Keesey RE (1998) Defense of differing body weight set points in diet-induced obese and resistant rats. Am J Physiol Regul Integr Comp Physiol 274, R412-R419.

306. Miller WH Jr, Faust IM, Goldberger AC, et al. (1983) Effects of severe long-term food deprivation and refeeding on adipose tissue cells in the rat. Am J Physiol Endocrinol Metab 8, E74-E80.

307. Yang MU, Presta E \& Bjorntorp P (1990) Refeeding after fasting in rats: effects of duration of starvation and refeeding on food efficiency in diet-induced obesity. Am J Clin Nutr 51, 970-978.

308. Shi H, Akunuru S, Bierman JC, et al. (2009) Diet-induced obese mice are leptin insufficient after weight reduction. Obesity 17, 1702-1709.

309. Gullicksen PS, Hausman DB, Dean RG, et al. (2003) Adipose tissue cellularity and apoptosis after intracerebroventricular injections of leptin and 21 days of recovery in rats. Int J Obes 27, 302-312.

310. Qian H, Azain MJ, Hartzell DL, et al. (1998) Increased leptin resistance as rats grow to maturity. Proc Soc Exp Biol Med 219, 160-165. 